\title{
Temporal source evolution and crustal contamination at Lopevi Volcano, Vanuatu Island Arc
}

\author{
Aurélien Beaumais ${ }^{a}$, Gilles Chazot $^{a, *}$, Laure Dosso $^{b}$, Hervé Bertrand $^{c}$
}

\begin{abstract}
a Université de Brest (UBO), UMR 6538, Domaines Océaniques, Institut Universitaire Européen de la Mer, place Copernic, 29280 Plouzané, France

${ }^{\mathrm{b}}$ CNRS-UMR6538, Ifremer, Département Géosciences Marines, 29280 Plouzané, France

c UMR-CNRS 5570, Laboratoire de Géologie de Lyon, Ecole Normale Supérieure de Lyon et Université Lyon 1 , 69364 Lyon, France
\end{abstract}

*: Corresponding author : Gilles Chazot, email address : $\underline{\text { Chazot@univ-brest.fr }}$

\begin{abstract}
:
Here we present a new geochemical study of Lopevi volcano, one the most active volcanoes in the Vanuatu island arc. We focus on the temporally well-defined sequence of lava flows emitted since 1960 , and for the first time, on pre-1960 volcanic products, including high-MgO basalts and felsic andesites, the most evolved lavas sampled so far on this island. This work reports the first $\mathrm{Pb}$ and $\mathrm{Hf}$ isotopic study of lavas from Lopevi island. These lavas display correlations between differentiation indexes such as $\mathrm{SiO}_{2}$ content and isotopic ratios. The felsic andesites extend the known correlations with both the least $(\mathrm{Sr}-\mathrm{Pb})$ and the most $(\mathrm{Nd}-\mathrm{Hf})$ radiogenic isotopic compositions on the island. Our results confirm that the rising magma interacted with the sub-arc crust. Assimilation-Fractional Crystallization (AFC) quantitative modeling of trace element ratios and isotopic compositions requires $1 \%$ and $10 \%$ of assimilated partial melts of a mafic oceanic crust to account for the pre- and post- 1960 lavas, respectively. The post-1960 lavas differ from the former lavas emitted $\sim 20$ years earlier by enrichments in fluid mobile elements ( $\mathrm{K}, \mathrm{Ba}, \mathrm{Rb} \ldots)$, Th, and Light Rare Earth Elements (LREE). We ascribe these features to slight variations in the metasomatic agent added to the sub-arc mantle and ultimately derived from the subducted lithosphere. However, the contrasting time scales involved in subducted lithosphere dehydration and magma genesis, relative to the time elapsed between eruptions of the two lava series, suggest that two different portions of mantle which have undergone slightly different metasomatism, gave birth to the Lopevi lavas. These distinct magmas are still present beneath the volcano.
\end{abstract}

\section{Highlights}

New geochemical study with $\mathrm{Hf}-\mathrm{Pb}$ isotopes of Lopevi, including recent and old lavas Evidences for interactions between ascending magmas and sub-arc crust - Evidence for short time scale mantle source variations ( 20 years) - Involvement of a different metasomatic agent in the pre- and post1960 lavas

Keywords: Lopevi ; Vanuatu ; Geochemistry ; Isotopes ; Subduction ; Mantle source 


\section{Introduction}

Intra-oceanic arcs are a privileged target for understanding the subduction process and for investigating the mantle source(s) of associated magmatism, because in this context the crustal contamination of mantle derived magmas is limited compared to the active continental margins setting, where the crust is thicker and chemically heterogeneous (e. g., Hildreth and Moorbath, 1988 and Woodhead, 1989). However the magnitude of this contamination process remains poorly constrained in these intra-oceanic arcs and is not easy to identify due to potentially similar chemical and isotopic compositions between the contaminant (the oceanic crust) and the rising magmas.

The Vanuatu island arc is an intra-oceanic arc where near-primitive magmas such as picrites, ankaramites or high $\mathrm{MgO}$ basalts are commonly erupted at several volcanic centers, giving the opportunity to observe a straightforward geochemical mantle source signature.

According to along-arc geochemical studies, the Vanuatu lava compositions vary from low $\mathrm{K}$ tholeiite to shoshonite series, with some high $\mathrm{Mg}$ andesites emitted in the southernmost seamounts (Monzier et al., 1997). Isotopic studies suggest that Indian and Pacific mantle reservoirs coexist beneath the Vanuatu island arc (Crawford et al., 1995). The high inter- and 
intra-islands geochemical variability observed is mainly related to elemental and isotopic heterogeneities in the sub-arc mantle wedge (Greene et al., 1994) and to variable addition of the subduction component along the arc (Peate et al., 1997). A few detailed studies have been focused on the origin of the primitive magmas and/or the geochemical evolution of a single volcanic system, on the scale of one island. Such studies include Merelava (Barsdell, 1988), Epi (Barsdell and Berry, 1990), Aoba (Eggins, 1993; Sorbadere et al., 2011), Efate (Raos and Crawford, 2004), Tanna (Métrich et al., 2011) and Lopevi (Handley et al., 2008).

We present a new geochemical study of the Lopevi volcano (Figure 1), based on the temporally well-defined sequence of lava flows emitted since 1960, and on older lavas which include high $\mathrm{MgO}$ basalts as well as andesites, the most evolved rocks found on the island. This study reports for the first time geochemical data on pre-1960 samples and the first $\mathrm{Pb}$ and $\mathrm{Hf}$ isotopic compositions from Lopevi Island.

\section{Geological setting and previous work}

The Vanuatu arc is made up of three parallel chains of volcanic islands located along the boundary of the SW Pacific plate: the western belt, the eastern belt, and the presently active central chain (Fig. 1). The aerial part of the Vanuatu central arc stretches along $1200 \mathrm{~km}$ from Ureparapara in the north to Hunter in the south. It is the surface expression of the fast subduction of the Australia plate beneath the North Fiji Basin which reaches $118 \mathrm{~mm} \cdot \mathrm{a}^{-1}$ at Tanna (Taylor et al., 1995; Calmant et al., 2003).

Tectonics of the SW Pacific is marked by the confrontation between the two large Australia and Pacific plates. The present convergence is characterized by a large deformed area of more than $1000 \mathrm{~km}$, the North Fiji Basin and is expressed by two opposite subductions: the 
westward Tonga-Kermadec and the eastward Solomon-Vanuatu. This is the result of a 25 m.y. long and complex tectonic history (MacFarlane et al., 1988; Greene et al., 1994). Ancient westward subduction of the Pacific plate beneath the Australia plate has given birth to the Vitiaz volcanic arc (25-14 Ma) from the Solomon to the Tonga islands and corresponds to the Western Belt (Mitchell and Warden, 1971) as shown in figure 1a, b. This subduction probably stopped when the Ontong-Java plateau collided with the Solomon Islands in the north (Meffre and Crawford, 2001; Mann and Taira, 2004).

As convergence continued, the North Fiji Basin began to open 12 Ma ago (Auzende et al., 1995). This convergence is marked 7 million years ago by the eastward diving of the Australia plate beneath the North Fiji Basin at the present place of the Vanuatu trench, giving birth to the Eastern Belt (Fig. 1a). At $\sim 6 \mathrm{Ma}$, the active volcanic arc (Central Chain) moved closer to the trench, in response to the steepening of the slab diving angle to $70^{\circ}$ (Pascal et al., 1978).

Between 3 and 1.5 Ma, the subduction-collision of the D'Entrecasteaux Ridge (an ancient Eocene arc) near Epi latitude (South of Lopevi) was a major tectonic event, producing a transverse fault system by compression in the central part of the arc (Collot et al., 1985; Greene et al., 1994). The collision zone shifted northward and is now located in front of Aoba (Fig. 1b), marked by the lack of trench and by the deceleration of the subducting plate to $3.5 \mathrm{~cm} \cdot \mathrm{a}^{-1}$. A slab detachment between Ureparapara and Vanua Lava in the north and between Ambrym and Efate occurred within the last million years (Châtelain et al., 1992; Monzier et al., 1997). Further south, the Loyalty ridge still collides with the Vanuatu arc close to $22^{\circ} \mathrm{S}$ (Monzier et al., 1993). The North Loyalty basin, composed of a Middle Eocene oceanic crust overlain by $\sim 650 \mathrm{~m}$ of mainly volcanoclastics sediments (Andrew et al., 1973), is currently subducting at $9 \mathrm{~cm} \cdot \mathrm{a}^{-1}$ in front of Efate. 
103 Strong geochemical variations along the Vanuatu arc have been well described by several

104 groups based on major and trace element contents (Barsdell et al., 1982; Dupuy et al., 1982;

105 Monzier et al., 1997; Peate et al., 1997) and $\mathrm{Sr}, \mathrm{Nd}, \mathrm{Pb}$, and Hf isotopic compositions

106 (Briqueu et al., 1994; Crawford et al., 1995; Peate et al., 1997; Laporte et al., 1998; Turner et

107 al., 1999; Pearce et al., 2007; Heyworth et al., 2011). Low K arc-tholeiites erupted before 2-3

108 Ma, are described as "normal suites" and show a Pacific-like mantle isotopic signature. Since

109 the onset of the subduction-collision of the D'Entrecasteaux Ridge, lavas are characterized by

110 a strong enrichment in $\mathrm{K}_{2} \mathrm{O}$, large ion lithophile elements (LILE), and LREE and by an

111 isotopic composition shifted toward an Indian-like mantle signature with radiogenic $\mathrm{Sr}$ and

112 high ${ }^{207} \mathrm{~Pb} /{ }^{204} \mathrm{~Pb}$ and ${ }^{208} \mathrm{~Pb} /{ }^{204} \mathrm{~Pb}$ isotope ratios (Dupuy et al., 1982; Briqueu et al., 1994; Baker

113 and Condliffe, 1996; Monzier et al., 1997; Peate et al., 1997; Laporte et al., 1998). The most

114 recent studies argue for a westward upwelling of an enriched asthenospheric mantle from the

115 back arc in front of the D'Entrecasteaux collision zone to explain the observed chemical

116 differences (Monzier et al., 1997; Peate et al., 1997; Pearce et al., 2007; Heyworth et al., 117 2011).

118 Lopevi is one of the most active volcanoes of the archipelago. This small conical island, $7 \mathrm{~km}$

119 large and rising up to $1413 \mathrm{~m}$, is composed of two distinct cones. The older one presents a

120 summit crater with little fumarole activity. The most recent crater, $1150 \mathrm{~m}$ high, appeared

121 during the 1963 eruptive phase (Williams and Curtis, 1964; Warden, 1967) and is breached to

122 the NW. This strato-volcano has been active since historical time both at summit and flank

123 vents, with different eruption styles, including explosive basaltic sub-plinian eruptions

124 associated with pyroclastic flows (e.g. 1960 and 2003 eruptions) and effusive activities. The

125 later produced lava flows that reached the coast and came mainly from the 1963 parasitic

126 crater or from excentric vents opened on the western flank along a NW-SE-trending fissure

127 system (Warden, 1967). Eruptive cycles of 15 to 20 years have been observed since the mid- 
$12819^{\text {th }}$ century. The last major eruptions occured in $1939,1960-1965,1980$, and $1998-2008$.

129 Lopevi shows a strong tectonic control, as the neighbouring island of Ambrym (Picard et al.,

130 1995) since these volcanoes are constructed on transverse fractures (Greene et al., 1988)

131 which are interpreted as major active transcurrent wrench faults related to the

132 D’Entrecasteaux Ridge collision (Fig.1).

133

134

135

136

137 Thirty five samples from different lava flows were collected on the Lopevi island during

\section{Sampling and analytical techniques}

fieldwork in September 2008 and 2009 (Fig. 2). Samples are more or less vesicular basalts and basaltic andesites with a porphyritic texture. Some samples belong to the well defined post-1960 activity while others pre-1960 samples were collected around the older summit crater and in deep gullies in the older part of the island. Some more differentiated samples such as andesitic pebbles are found along beaches south of the island, at the lower part of gullies. All samples are very fresh, with loss on ignition values (LOI) lower than $0.5 \mathrm{wt} \%$.

\subsection{Major and trace elements}

All samples were analysed for major and trace elements. Major element analyses of whole rock samples were performed on glass fusion beads by X-Ray Fluorescence spectrometry using a Philips PW 1404 (LGL, Lyon). Relative standard deviations are 1\% for $\mathrm{SiO}_{2}$ and 2\% for the other major elements, except for low concentrations $(<0.50 \%)$ for which the absolute standard deviation is 0.01 . Major element compositions for minerals (phenocrysts and microlites) of 12 samples were carried out on thin sections with a Cameca SX100 Electron 
153 Probe Micro Analysis (Centre Microsonde Ouest - Plouzané). The operating conditions were

$15415 \mathrm{kV}$ accelerating voltage, $10 \mathrm{nA}$ beam current, and $15-30 \mathrm{~s}$ counting time according to the 155 element.

156 Trace element concentrations were determined in solution by HR-ICP-MS Thermo Fisher

157 Element-II ${ }^{\circledR}$ (IUEM, Plouzané). Samples were measured according to the procedures

158 described by Barrat et al. (1996) and by Chauvel et al. (2011). Trace element concentrations

159 were calculated using a machine drift correction based on the 1-element $(\mathrm{Tm})$ or 3-element

160 (Be, In, Tm) spike with a mass-based interpolation. Precision for most elements is better than

$1612 \% \operatorname{RSD}(3 \% \mathrm{RSD}$ for $\mathrm{U}$ and Th). Accuracy is better than $5 \%$ for most elements relative to

162 suggested values for international standards BCR-2 (Jochum and Brueckner, 2008) and JB-2

163 (Peate et al., 2009) (Table 1).

164

\subsection{Isotopes}

167 Based on major and trace element concentrations, 15 samples were selected for $\mathrm{Pb}, \mathrm{Sr}, \mathrm{Nd}$

168 and Hf isotopic measurements. They are representative of the different volcanic phases of

169 Lopevi and of the whole extent of magma differentiation. Chemical separation for isotopic 170 measurements was carried out in a class 10000 clean room (Ifremer). From a single sample

171 digestion, we used a combined procedure for separating $\mathrm{Pb}, \mathrm{Sr}, \mathrm{Nd}$, and $\mathrm{Hf}$ in 5 steps

172 chromatography. (1) About $700 \mathrm{mg}$ of whole rock powder were dissolved for $72 \mathrm{~h}$ with a 3:1

173 concentrated HF-HBr mixture in teflon Savillex ${ }^{\circledR}$ beakers at about $80^{\circ} \mathrm{C}$ and evaporated to

174 dryness. (2) $\mathrm{Pb}$ was first separated from other elements using the classical HBr-anion-

175 exchange resin technique (AG1-X8 100-200mesh) of Manhes et al. (1984). (3) The Pb-free

176 fraction obtained was loaded onto a $\sim 6.5 \mathrm{~cm}^{3}$ cation-exchange resin BioRad ${ }^{\circledR}$ (AG50-8X 200-

177400 mesh) to separate from the major elements the High Field Strength Elements (HFSE) 
178 with a mixed $0.5 \mathrm{M} \mathrm{HCl} / 0.15 \mathrm{M} \mathrm{HF}$, Sr with $3 \mathrm{M} \mathrm{HCl}$, and rare earth elements (REE) with

$1793.6 \mathrm{M} \mathrm{HNO}_{3}$. (4) $\mathrm{Hf}$ was further separated from Ti using a modified version of the method

180 described by Yang et al. (2010). The HFSE fraction was loaded onto a column filled with 100

$181 \mathrm{mg}$ of Eichrom ${ }^{\circledR}$ Ln-resin. Ti was removed with $15 \mathrm{~mL}$ of $6 \mathrm{M} \mathrm{HCl}-\mathrm{H}_{2} \mathrm{O}_{2}$ mixture and the Hf-

$182 \mathrm{Zr}$ fraction was eluted with $2 \mathrm{~mL}$ of $2 \mathrm{M}$ HF. (5) Finally Nd was isolated from the other REE

183 using the Eichrom ${ }^{\circledR}$ Ln-resin technique adapted from Richard et al. (1976) with diluted HCl.

184 Total procedural chemistry blanks during the course of this work were less than 58 pg for Hf,

$1855 \mathrm{pg}$ for $\mathrm{Nd}, 143 \mathrm{pg}$ for $\mathrm{Sr}$, and $50 \mathrm{pg}$ for $\mathrm{Pb}$. These values are totally negligible relative to the

186 amounts of element present in the samples.

$187 \mathrm{Sr}$ and $\mathrm{Nd}$ isotope ratios were measured in static mode using a solid source Thermo Fisher ${ }^{\circledR}$

188 Triton TI-MS (Thermo Ionization - Mass Spectrometer) at IUEM (Plouzané, France) and a

189 MAT26X TI-MS (MAT261 upgraded by Spectromat) at Ifremer (Plouzané, France). All

190 measured ratios were fractionation corrected using ${ }^{88} \mathrm{Sr} /{ }^{86} \mathrm{Sr}=8.3752$ and ${ }^{146} \mathrm{Nd} /{ }^{144} \mathrm{Nd}=$

1910.7219 . The average ${ }^{87} \mathrm{Sr} /{ }^{86} \mathrm{Sr}$ ratio measured for the NBS 987 standard was $0.710271 \pm 14$

192 (2SD, for 12 runs) on the Triton, and $0.710244 \pm 18$ (2SD, for 5 runs) on the MAT26X. No

193 correction was applied. The average ${ }^{143} \mathrm{Nd} /{ }^{144} \mathrm{Nd}$ ratio measured for the JNdi-1 standard was

$1940.512105 \pm 12$ (2SD, for 13 runs) and $0.511846 \pm 7$ (2SD, for 6 runs) for the La Jolla standard.

$195 \mathrm{~Pb}$ and Hf isotopic ratios were measured using a Thermo Fisher ${ }^{\circledR}$ Neptune MC-ICP-MS

196 (Multi Collector - Inductively Coupled Plasma - Mass Spectrometer) at IUEM. The Hf mass

197 bias was corrected using an exponential law and assuming a ${ }^{179} \mathrm{Hf} /{ }^{177} \mathrm{Hf}=0.7325$. The average

$198{ }^{176} \mathrm{Hf} /{ }^{177} \mathrm{Hf}$ ratio measured for the JMC475 was $0.282152 \pm 11$ (2SD, for 58 runs). Pb isotopic

199 ratios were measured using the thallium addition technique in order to correct the mass bias

200 (White et al., 2000). The NIST981 standard was run every two or three samples to correct all

$201 \mathrm{~Pb}$ isotopic ratios by standard bracketing with the value recommended by Galer and 
Abouchami (1998). The average ${ }^{206} \mathrm{~Pb} /{ }^{204} \mathrm{~Pb},{ }^{207} \mathrm{~Pb} /{ }^{204} \mathrm{~Pb},{ }^{208} \mathrm{~Pb} /{ }^{204} \mathrm{~Pb}$ ratios measured for the NIST981 were respectively $16.930 \pm 3,15.483 \pm 4$, and $36.670 \pm 12$ (2SD, for 29 runs).

\section{Results}

\subsection{Major and trace element results}

Lopevi lavas display a medium-K calc-alkaline series (Fig. 3) and are mostly basalts and basaltic andesites ranging from 49.5 to $56 \mathrm{wt} \% \mathrm{SiO}_{2}$, except for two acid andesite pebbles at $\sim 61$ wt $\% \mathrm{SiO}_{2}$ (only one data point visible in Fig. 3 because of their very similar chemical composition). Post-1960 lavas are slightly more enriched in $\mathrm{K}_{2} \mathrm{O}$ than the older ones (Fig. 3).

Basalts and basaltic andesites are composed of abundant euhedral to subeuhedral phenocrysts of clinopyroxene $\left(\mathrm{Wo}_{35-45}, \mathrm{Fs}_{6-17}, \mathrm{En}_{41-48}\right)$, plagioclase $\left(\mathrm{An}_{78-92}\right)$ and olivine $\left(\mathrm{Fo}_{70-90}\right)$, surrounded by a glassy to fine grained matrix composed of microcrysts of clinopyroxene $\left(\mathrm{Wo}_{7-37}, \mathrm{Fs}_{14-36}, \mathrm{En}_{26-66}\right)$, plagioclase $\left(\mathrm{An}_{30-89}\right)$, olivine $\left(\mathrm{Fo}_{60-78}\right)$ and $\mathrm{Fe}-\mathrm{Ti}$ oxides. Phenocrysts from the basaltic-andesite LO14 show more evolved compositions with clinopyroxene $\left(\mathrm{Wo}_{8}\right.$ 37, $\left.\mathrm{Fs}_{33-66}, \mathrm{En}_{42-61}\right)$, plagioclase $\left(\mathrm{An}_{55-85}\right)$ and olivine $\left(\mathrm{Fo}_{74}\right)$. Common tendency to aggregation of phenocrysts is observed. Andesites are composed of abundant tabular, sometimes zoned, plagioclases $\left(\mathrm{An}_{56-68}\right)$ and less abundant clinopyroxene phenocrysts $\left(\mathrm{Wo}_{36-39}, \mathrm{Fs}_{15-20}, \mathrm{En}_{40-46}\right)$.

Olivine is absent and some scarce orthopyroxene phenocrysts $\left(\mathrm{Wo}_{2-3}, \mathrm{Fs}_{31-52}, \mathrm{En}_{44-65}\right)$ are found. Those phenocrysts are set in a fine grained matrix composed of microcrysts of plagioclase $\left(\mathrm{An}_{23-60}\right)$, clinopyroxene $\left(\mathrm{Wo}_{8-47}, \mathrm{Fs}_{25-44}, \mathrm{En}_{29-52}\right)$ and $\mathrm{Fe}-\mathrm{Ti}$ oxide. Overall, crystals set in the more evolved rocks are impoverished in $\mathrm{Mg}$ and in $\mathrm{Ca}$, compared to others, as observed also in the microcrysts compared to the phenocrysts in one sample. 
Major element variation diagrams (Fig. 4) show that some basalts have relatively high $\mathrm{MgO}$ content reaching $7.8 \mathrm{wt} \%$ and that the post-1960 lavas are also slightly more enriched in $\mathrm{Al}_{2} \mathrm{O}_{3}$ than the older ones. $\mathrm{MgO}, \mathrm{Fe}_{2} \mathrm{O}_{3}$, and $\mathrm{CaO}$ are negatively correlated with silica content, with a slope change at $\sim 51 \mathrm{wt} \% \mathrm{SiO}_{2}$ for the post-1960 lavas and at $\sim 52 \mathrm{wt} \% \mathrm{SiO}_{2}$ for the older ones, whereas $\mathrm{Na}_{2} \mathrm{O}$ and $\mathrm{K}_{2} \mathrm{O}$ show positive correlations (Figs. 3 and 4, $\mathrm{Fe}_{2} \mathrm{O}_{3}, \mathrm{CaO}$, and

$232 \mathrm{Na}_{2} \mathrm{O}$ are not shown). $\mathrm{Al}_{2} \mathrm{O}_{3}$ is positively correlated with silica content for low $\mathrm{SiO}_{2}$ values $233(<51-52 \mathrm{wt} \%)$ and negatively correlated for higher values.

234 Chondrite-normalised rare earth element (REE) patterns (Fig. 5a) have slight to moderate 235 enrichment in the Light REE (LREE 20 to 30 times the chondritic values) relative to Heavy 236 REE (HREE) which draw an almost flat pattern ( $~ 10$ to 20 times the chondritic values). Pre237 and post-1960 lavas show overall similar patterns, but the former display a larger range of 238 compositions, in line with their higher Si content.

239 The extended trace element patterns (Fig. 5b) are typical of arc magmas with an enrichment in 240 fluid mobile elements $(\mathrm{Rb}, \mathrm{Ba}, \mathrm{U}, \mathrm{K}, \mathrm{Pb}, \mathrm{Sr})$, and a depletion in high field strength elements 241 (HFSE: Nb, Ta, Hf, Zr, Ti) relative to the REE. Overall post-1960 lavas are more 242 homogeneous than the pre-1960 lavas. The high MgO basalt LO20 has the lowest trace 243 element abundance, and its trace element pattern is slightly different from the others. Some 244 lavas display negative Eu anomalies which are more developed in the most evolved lavas. 245 Lopevi lavas display a moderate enrichment in fluid mobile elements, and relatively low $246 \mathrm{La} / \mathrm{Yb}$ ratio (2-3) compared to other Vanuatu island lavas such as those facing the 247 D’Entrecasteaux ridge collision which display La/Yb ratios reaching $\sim 12$ (Fig. 5). Highly 248 incompatible elements (such as $\mathrm{Nb}$ and $\mathrm{Th}$ ) content increases during magmatic differentiation 249 (Fig. 6). Pre- and post-1960 lavas display two distinct positive trends with distinct $\mathrm{Th} / \mathrm{Nb}$ $250 \operatorname{ratios}(\sim 0.45$ vs. 0.55 , respectively), supporting the existence of two slightly distinct 
magmatic series at Lopevi. However the felsic andesites, belonging to the pre-1960 group, are aligned on the post-1960 trend.

\subsection{Isotopic results}

The Lopevi samples show a restricted isotopic range compared to the whole range reported from Vanuatu volcanic islands (Fig. 7). Their ${ }^{87} \mathrm{Sr} /{ }^{86} \mathrm{Sr}$ ratios vary from 0.70392 to 0.70409 . ${ }^{143} \mathrm{Nd} /{ }^{144} \mathrm{Nd}$ and ${ }^{176} \mathrm{Hf} /{ }^{177} \mathrm{Hf}$ ratios show very small variations from 0.51296 to 0.51303 and from 0.28316 to 0.28318 , respectively. Variations in $\mathrm{Pb}$ isotopic compositions are also limited, and range from 18.44 to 18.51 for ${ }^{206} \mathrm{~Pb} /{ }^{204} \mathrm{~Pb}$, from 15.53 to 15.55 for ${ }^{207} \mathrm{~Pb} /{ }^{204} \mathrm{~Pb}$, and from 38.38 to 38.44 for ${ }^{208} \mathrm{~Pb} /{ }^{204} \mathrm{~Pb}$. This limited isotopic variation does not bring out significant isotopic differences between the pre- and the post-1960 lavas. However the new Sr-Nd isotopic analyses extend the compositional range reported by Handley et al. (2008) toward lower ${ }^{87} \mathrm{Sr} /{ }^{86} \mathrm{Sr}$ ratios and higher ${ }^{143} \mathrm{Nd} /{ }^{144} \mathrm{Nd}$ ratios recorded in the more differentiated products (Fig. 7a).

Lopevi lavas have relatively high ${ }^{87} \mathrm{Sr} /{ }^{86} \mathrm{Sr},{ }^{207} \mathrm{~Pb} /{ }^{204} \mathrm{~Pb}$ and ${ }^{208} \mathrm{~Pb} /{ }^{204} \mathrm{~Pb}$ values, and intermediate ${ }^{143} \mathrm{Nd} /{ }^{144} \mathrm{Nd},{ }^{176} \mathrm{Hf} /{ }^{177} \mathrm{Hf}$, and ${ }^{206} \mathrm{~Pb} /{ }^{204} \mathrm{~Pb}$ values compared to the isotopic composition range reported for the Vanuatu lavas (Peate et al., 1997; Laporte et al., 1998; Turner et al., 1999; Pearce et al., 2007). This isotopic signature is intermediate between the isotopic signatures of the lavas emitted in front of the collision zone and those emitted away in the northern and the southern part of the arc. Lopevi lavas fall broadly in the Indian MORB field in the $\mathrm{Pb}-\mathrm{Pb}$ and $\mathrm{Hf}-\mathrm{Nd}$ isotopic spaces, having high ${ }^{207} \mathrm{~Pb} /{ }^{204} \mathrm{~Pb}$ and ${ }^{208} \mathrm{~Pb} /{ }^{204} \mathrm{~Pb}$ values for a given ${ }^{206} \mathrm{~Pb} /{ }^{204} \mathrm{~Pb}$ value, and low ${ }^{143} \mathrm{Nd} /{ }^{144} \mathrm{Nd}$ ratio for a given ${ }^{176} \mathrm{Hf} /{ }^{177} \mathrm{Hf}$ value (Fig. 7). However, in the Sr-Nd space (Fig. 7a), Lopevi lavas plot outside the MORB fields, displaying 
275 higher ${ }^{87} \mathrm{Sr} /{ }^{86} \mathrm{Sr}$ ratios as commonly described in island arc lavas, and fall within the field of 276 the North Loyalty Basin sediments.

\section{Discussion}

\subsection{Fractional Crystallization}

Lopevi arc lavas include only a small proportion of differentiated materials. Lopevi lavas host 284 "classical" mineral assemblage: olivine, clinopyroxene, plagioclase, and Fe-Ti oxides. In the more evolved lavas, olivine disappears while orthopyroxene is present. No hydrous minerals 286 like amphibole are present.

Major element covariation diagrams (Fig. 4) suggest by their trends and their inflections a two- stage crystallization. The first stage is characterized by the removal of olivine and 289 clinopyroxene as seen by the decrease of $\mathrm{MgO}$ content from 8 to $5 \%$ (Fig. 4). The inflection of the $\mathrm{MgO}-\mathrm{SiO}_{2}$ trend at $51-52$ wt. $\% \mathrm{SiO}_{2}$ is related to the onset of $\mathrm{Al}_{2} \mathrm{O}_{3}$ decrease in the

291 lavas and to plagioclase fractionation. This change is also recorded by the Eu negative

292 anomaly (which is compatible in plagioclase) shown in the trace element patterns of the more 293 evolved samples. Thereby the appearance of low-Ca orthopyroxene in the most evolved rocks 294 is probably related to the abundance of plagioclase which integrates a large amount of $\mathrm{CaO}$ 295 and the lack of elevated water pressure to stabilize amphibole.

296 Least square modelling of the major element data (Bryan et al., 1969) accounts successfully 297 for the first stage of fractional crystallization in the most mafic rocks until $51 \% \mathrm{SiO}_{2}$ and 298 gives similar results to those of Handley et al. (2008), with a $\sim 30 \%$ degree of crystal 299 fractionation. However the modelling fails to account for the second stage of crystallization, 
suggesting that an additional process is involved during magmatic differentiation. This is also suggested also by the change of $\mathrm{Nb} / \mathrm{Th}$ ratios during the differentiation of the pre-1960 lavas (Fig. 6).

\subsection{Assimilation - Fractional Crystallization (AFC)}

\subsubsection{Isotopic evidence}

Classical long-lived radiogenic systems ( $\mathrm{Sr}-\mathrm{Nd}-\mathrm{Pb}-\mathrm{Hf})$ are a powerful tool to spot magma contamination, provided that the isotopic composition of the contaminant is distinct from the composition of the magma. In spite of a rather restricted range in isotopic compositions, the Lopevi lavas display a negative $\mathrm{Sr}-\mathrm{Pb}$ and a positive $\mathrm{Nd}-\mathrm{Hf}$ correlation with the differentiation indexes $\left(\mathrm{SiO}_{2}, \mathrm{MgO}\right.$, Th, $\left.\mathrm{La}\right)$, extending the correlations reported in Handley et al. (2008) towards lower ${ }^{87} \mathrm{Sr} /{ }^{86} \mathrm{Sr}$, higher ${ }^{143} \mathrm{Nd} /{ }^{144} \mathrm{Nd}$ and higher $\mathrm{SiO}_{2}$ values (Fig. 8, Hf isotopes not shown). It suggests that a contamination process occurred during the ascent of the magma toward the surface and that the contaminant is less ( $\mathrm{Sr}$ and $\mathrm{Pb})$ and more $(\mathrm{Nd}$ and $\mathrm{Hf})$ radiogenic than the most evolved samples. This is in agreement with Handley et al. (2008) who identified contamination in the post-1960 lavas using Sr, Nd, Ra, and Th isotopes. These authors argued for the assimilation of a small degree of partial melt $(2-10 \%)$ of a $>380 \mathrm{Ka}$ old mafic oceanic crust, of MORB composition, rejecting the hypothesis of bulk assimilation of oceanic crust and magma mixing process. 
324 Contamination by the oceanic crust is investigated using an AFC model (DePaolo, 1981). The

325 equation used is: $C_{m}=C^{0}{ }_{m} F^{-z}+(r / r-1)\left(C_{a} / z\right)\left(1-F^{-z}\right)$, with $z=(r+D-1) /(r-1) . \mathrm{C}_{\mathrm{a}}$ and $\mathrm{C}_{\mathrm{m}}$ are

326 the concentrations in the contaminant and in the magma respectively. D corresponds to the

327 bulk partition coefficient, $\mathrm{F}$ is the fraction of remaining melt and $\mathrm{r}$ is the ratio of assimilation

328 rate to fractional crystallization rate. The compositions of the parental magma as the starting

329 end member are chosen among the basalts with the highest $\mathrm{MgO}$ content (LO03 and LO15 for

330 post- and pre-1960 groups, respectively). The crust underneath Lopevi is a likely contaminant

331 composed of oceanic crust and of some former magmatic intrusives. However its precise

332 composition remains unknown. An N-MORB trace element composition from Sun and

333 McDonough (1989) is taken as representative of this crust. Values for the isotopic

334 composition of the contaminant are chosen to obtain the best fit with our data set. These

335 values are included into the isotopic composition range reported for the North Loyalty Basin

336 by Briqueu and Lancelot (1983), Briqueu et al. (1994), and Peate et al. (1997), except for the

337 Hf isotopic value which is significantly different from the single value reported by Pearce et

338 al. (2007) and for the low ${ }^{206} \mathrm{~Pb} /{ }^{204} \mathrm{~Pb}$ value required for the recent contaminant. Assimilation

339 of oceanic crust as partial melts (rather than bulk crust) is investigated. It has for main effect

340 to increase the incompatible element concentration of the contaminant, while its $\mathrm{Pb}, \mathrm{Sr}, \mathrm{Hf}$

341 and $\mathrm{Nd}$ isotopic compositions remain unchanged. The trace element concentrations of the

342 assimilated melts are calculated using a non-modal batch melting model (Shaw, 1970) of an

343 N-MORB (Sun and McDonough, 1989) involving 1 and $10 \%$ of melts, for the pre- and the

344 post- 1960 contaminants, respectively.

345 Our model provides a good fit of the data in diagrams involving combined isotope ratios

346 (insensitive to the fractional crystallization) or trace element and isotopic ratios (Fig. 9 and

347 10). Notably, the two distinct sets of $C_{a}$ (with $1 \%$ and $10 \%$ of assimilated partial melts for 
pre- and post- 1960 lavas, respectively) and low $(\leq 0.3) \mathrm{r}$ parameters (Table 2$)$ can account for

349 the separate pre- and post- 1960 lava trends.

350 The pre-1960 lavas model requires a crustal partial melt contaminant with high U/Pb and

$351 \mathrm{Ba} / \mathrm{Yb}$, associated with a low $\mathrm{r}$, while the post-1960 model requires a contaminant with lower

$352 \mathrm{U} / \mathrm{Pb}, \mathrm{Ba} / \mathrm{Yb}$ ratios associated with a higher $\mathrm{r}$ value (Table 2). As seen in figures $9 \mathrm{a}$ and $9 \mathrm{~b}$,

353 the post-1960 model requires a lower ${ }^{206} \mathrm{~Pb} /{ }^{204} \mathrm{~Pb}$ than needed for the pre-1960 lavas.

354 Ratios such as $\mathrm{U} / \mathrm{Pb}$ and $\mathrm{Ba} / \mathrm{Yb}$ ( $\mathrm{U}$ and $\mathrm{Ba}$ being respectively more incompatible than $\mathrm{Pb}$ and

$355 \mathrm{Yb}$ ) are very sensitive to the degree of partial melting, while $\mathrm{Sr}-\mathrm{Nd}-\mathrm{Pb}-\mathrm{Hf}$ isotopic ratios are

356 not affected by this process and remain constant. Two distinct partial melting degrees ( $1 \%$ for

357 pre- and $10 \%$ for post-1960 lavas) of a single N-MORB contaminant generate consistent $\mathrm{C}_{\mathrm{a}}$

358 values for both series. Variable degrees of partial melting could be related to distinct

359 conditions of pressure and temperature during assimilation or to a variable water content of

360 the contaminant. The $\mathrm{r}$ values in the model for the post-1960 series are higher than those

361 required for the older ones ( 0.3 versus 0.2$)$, indicating a higher assimilation / fractional

362 crystallization rate.

363 Many uncertainties remain in such models but our results are consistent with the model

364 presented by Handley et al. (2008), with similar degrees of partial melting of the contaminant

365 ( 1 and $10 \%$ vs. $2-10 \%$ ), and r values (0.2 and 0.3 vs. 0.25$)$. However we use a slightly more

366 radiogenic Sr contaminant in our model (0.7033 vs. 0.7025$)$ because a lower ${ }^{87} \mathrm{Sr} /{ }^{86} \mathrm{Sr}$ value

367 cannot explain the pre-1960 variations.

\subsection{Subduction component}


373 At the island arc scale, the Lopevi geochemical variations are limited (Monzier et al., 1997;

374 Peate et al., 1997). Nevertheless at the scale of Lopevi volcano, differences appear between 375 pre- and post-1960 lavas independently of the AFC process, especially when looking at trace 376 element ratios such as $\mathrm{Ba} / \mathrm{Yb}$ or $\mathrm{Th} / \mathrm{Nb}$ (Figs. 6 and 10), as shown by the lack of overlap in $377 \mathrm{Ba} / \mathrm{Yb}$ between both series (Fig. 10). The largest differences are observed in the most mafic 378 (MgO rich) lavas, where the contamination effect is assumed to be the lowest and where the 379 source signature is the most pronounced. Figure 11 shows the REE and trace element patterns 380 of the basalts with $\mathrm{MgO}>7$ wt. \%. Overall differences between both series are characterized 381 by a higher enrichment in fluid mobile elements ( $\mathrm{Rb}, \mathrm{Ba}, \mathrm{U}, \mathrm{K}, \mathrm{Pb}, \mathrm{Sr}$ ), in LREE (higher $382 \mathrm{La} / \mathrm{Yb}$ ) and in Th recorded in the post-1960 lavas. However the HFSE and HREE content are 383 almost similar in the most mafic lavas (Fig. 11).

384 The isotopic signatures of Lopevi lavas are affected by the AFC process but the most mafic 385 lavas from both series, which are supposed to be the least contaminated, have almost identical $386 \mathrm{Nd}, \mathrm{Pb}$ and $\mathrm{Hf}$ isotopic compositions (Fig. 9). Only the Sr isotopes show a slight difference 387 with more radiogenic ratios in the recent lavas.

\subsubsection{Mantle source composition}

391 Trace element variations in mafic lavas can reflect a change of 1) their mantle source

392 mineralogy, 2) variable degrees of partial melting, or 3) different mantle sources. The most 393 mafic post-1960 lavas have higher $\mathrm{La} / \mathrm{Yb}$ ratios ( 2.8 vs. 2.4$)$ than the older ones (Fig. 11). 394 As garnet incorporates some $\mathrm{Yb}$ amount in its structure, elevated $\mathrm{La} / \mathrm{Yb}$ ratios in lavas could 395 result from the melting of a garnet-bearing source at high pressure (Shimizu and Kushiro, 396 1975; Langmuir et al., 1977). However the observed differences between both series are 397 moderate and cannot be attributed to a significant change in the mantle source mineralogy. 
398 Changes in the partial melting degree of a single mantle source can also produce various trace 399 element compositions in mafic magmas, in particular a fractionation between the most and the 400 least incompatible elements. For example, while $\mathrm{Nb}$ is more incompatible than $\mathrm{Yb}$ during 401 partial melting processes, pre- and post-1960 Lopevi lavas have identical $\mathrm{Nb} / \mathrm{Yb}$ ratios $(\sim 0.6$

402 for high-MgO basalts). Accordingly, partial melting cannot account for the chemical

403 differences between the two series at Lopevi volcano.

404 In subduction zones, melting of the mantle wedge is triggered by the addition of a water-rich 405 component released from the subducted oceanic lithosphere (e.g. Tatsumi, 1986; Peacock, 1990; Grove et al., 2006). This water-rich component carries trace elements into the mantle

407 wedge and gives the typical enriched signature of arc magmas compared to MORB

408 (McCulloch and Gamble, 1991). However its exact nature (aqueous fluids or hydrous melt)

409 and origin (altered oceanic crust or sediments) remains largely debated (Elliott et al., 1997;

410 Hawkesworth et al., 1997; Eiler et al., 1998; Prouteau et al., 2001). Lopevi lavas show Nb/Yb 411 ratios similar to those found in MORB, indicating that the mantle in the subduction area was 412 as depleted as the MORB mantle before the subduction component addition. Other trace 413 element ratios involving fluid/melt mobile elements are higher than in MORB and document 414 the element flux derived from the subducted plate. Among these elements, $\mathrm{Ba}$ and $\mathrm{Pb}$ are 415 often used to indicate low T dehydration of the subducted lithosphere because they are highly 416 mobile in hydrous fluids (Brenan et al., 1995; Stalder et al., 1998; Kessel et al., 2005) whereas 417 Th is used as an indicator of sediment melting because Th/REE fractionation increases at high 418 T when sediments melt (Johnson and Plank, 1999; Kessel et al., 2005; Plank, 2005; Hermann 419 and Spandler, 2008).

420 Lopevi lavas are weakly enriched in incompatible elements compared to MORB which is 421 consistent with a moderate modification of their mantle source by a subduction component. $422 \mathrm{Th} / \mathrm{La}$ ratio is slightly higher than in MORB but the main enrichments affect $\mathrm{Ba}, \mathrm{Sr}$ and $\mathrm{Pb}$. 
423 Even if the participation of a sediment melt cannot be ruled out, it is clear that low T

424 dehydration fluids carried LILE into the Lopevi mantle source, in agreement with the high

$425 \mathrm{Ba} / \mathrm{Yb}$ and $\mathrm{Pb} / \mathrm{Ce}$ ratios of the Lopevi lavas.

426 Post-1960 lavas are enriched in $\mathrm{Ba}$ and $\mathrm{K}$ while the less differentiated samples, which are also

427 the less (or not at all) contaminated, have no significant differences in their Sr-Nd-Pb-Hf

428 isotopic compositions. From these observations, one can argue that pre- and post-1960 lavas

429 come from two different mantle sources beneath Lopevi. Both mantle portions have been

430 metasomatised with fluids from a same origin, consistent with their identical isotopic

431 composition, but the element flux was more elevated in the post-1960 mantle source, in

432 agreement with the higher $\mathrm{K}$ and $\mathrm{Ba}$ enrichment observed in these more recent lavas.

\subsection{Volcanological implications}

436 Several eruptions have been recorded at Lopevi volcano between 1864 and 1939, before the

437 volcano entered a period of quiescence for more than 20 years (Williams and Curtis, 1964).

438 Volcanic activity resumed in 1960 by a large basaltic plinian eruption which forced a

439 definitive evacuation of the people living on the island. This eruption marked the beginning of 440 a new eruptive cycle of the volcano, with the production of mafic olivine-bearing magmas and 441 the opening of the new lateral crater on the NW flank (Warden, 1967). During the following 442 years the main crater was only active at the beginning of the eruptions while the main activity 443 was concentrated in the new lateral cone or occurred along adjacent NW trending fissures.

444 The onset of this new activity cycle in 1960 was accompanied by a shift in the trace element 445 composition of the erupted magmas, as shown previously. The change occurred within a very 446 short time scale ( $\sim 20$ years) while the deep processes of magma formation and evolution 447 have been shown to appear on a larger time scale. Using the fractionation of $\mathrm{Ra}$ and $\mathrm{Th}$ in 
metasomatic fluids recorded by Ra-Th isotopes, Handley et al. (2008) estimated the metasomatism of the mantle wedge beneath Lopevi to have happened less than 8000 years ago, while the magmatic differentiation from basalt to basaltic andesite and the associated contamination was accomplished in less than 1000 years.

Taking these constraints all together indicates that fluid transfer from the subducted

453 lithosphere into the mantle wedge creates mantle portions with different trace element

454 compositions, probably in response to variable fluid flux in the mantle. Melting of at least two

455 different mantle regions beneath Lopevi created magmas with slight differences in their trace

456 element contents. These magmas followed different pathways from their source to the Lopevi

457 volcano through the crust in which they were differentiated and contaminated in separate

458 magma chambers beneath the volcano. The more enriched magma initiated the last volcanic

459 cycle at Lopevi, and, following different pathways to the surface, created a new emission 460 centre on the flank of the volcano.

461 The very short time scale of this shift indicates that the "older' and less enriched magma is 462 still present beneath the volcano and can erupt again from the summit crater in the years or 463 decades to come.

\section{Conclusions}

467 - New sampling of the Lopevi island increases the previous data set (mainly post-1960) of 468 Handley et al. (2008), providing insight into the older history of the volcano. Notably, the pre4691960 data set contains more differentiated rocks, up to $61 \mathrm{wt} \% \mathrm{SiO}_{2}$.

470 - Chemical and isotopic data on pre- and post-1960 lavas confirm the contamination of the 471 ascending magmas by partial melts derived from the oceanic crust beneath the volcano. AFC 
472 modelling requires $1 \%$ and $10 \%$ of assimilated crustal melts to account for the pre- and post-

4731960 lavas, respectively.

474 - Pre- and post-1960 lavas show different trace element compositions but very similar isotopic

475 ratios. These differences, unrelated to the contamination process, are ascribed to the partial

476 melting of different portions of the mantle, which have undergone slightly different

477 metasomatic fluid flux from the subducted oceanic lithosphere.

478 - The renewal of volcanic activity in 1960, after more than 20 years of quiescence, marks the

479 involvement of a new batch of magma coming from a different mantle source. However, the

480 contrasted time scales involved in the magma genesis at depth and the volcanological

481 evolution at the surface imply that the old magma is still present beneath the volcano but so

482 far unable to mix with the younger one.

483

484

\section{Acknowledgments}

486

487 We thank the Pole Spectrometry Ocean (Emmanuel Ponzevera, Phillipe Nonotte, Claire

488 Bassoullet, Céline Liorzou), Bleuenn Gueguen and Shasa Labanieh for their help to the data 489 acquisition. Paul Capiez is acknowledged for XRF analyses. This work was supported by the 490 ANR contract Arc-Vanuatu led by Bernard Pelletier. Esline Garaebiti and the people from the 491 Vanuatu Geohazards Observatory are warmly thanked for their help during the field trips. We 492 also thank the two reviewers for their valuable comments.

493

\section{$494 \quad$ Figure captions}


496 Figure 1: (a) Bathymetric map of the Vanuatu island arc. Inset: General map of the south-

497 west Pacific. (b) Interpretative map of the Vanuatu islands showing the general tectonic 498 setting adapted from Pelletier et al. (1998). The Back Arc Thrust Belt is the thrusting of the 499 Eastern belt on the North Fiji Basin (Calmant et al., 2003). The Vanuatu active arc (central 500 chain) is drawn in red, with small white triangles representing the active volcanoes. Inclined 501 hatching is used for islands belonging to the Western belt and to the Eastern belt. Simple 502 arrows indicate the convergent rate in $\mathrm{cm} \cdot \mathrm{a}^{-1}$ of the subducted plate from GPS data (Calmant 503 et al., 2003). Double arrows represent the divergent rates in $\mathrm{cm} \cdot \mathrm{a}^{-1}$ in the back arc domain 504 (Price and Kroenke, 1991; Auzende et al., 1994; Huchon et al., 1994; Pelletier et al., 1998). 505 The associated thin lines show the active spreading axes. Brown areas represent ridges and 506 plateaus (submarine relief) on the subducted plate. Dashed bold lines represent the major 507 faults and the associated half arrows represent the movement of each block. The dotted line in 508 the north represents the ancient Vitiaz trench lineament. The star indicates the location of the 509 DSDP (Deep Sea Drilling Project) hole 286.

511 Figure 2: (a) Location map of Lopevi samples (circles), and the main recent lava flows, 512 adapted from Handley et al. (2008). Circles represent the location of the samples from this 513 work, whereas triangles represent those studied by Handley et al. (2008). (b) Regional 514 bathymetric map of the central part of the Vanuatu arc, with the location of the Lopevi island.

516 Figure 3: $\mathrm{K}_{2} \mathrm{O}$ versus $\mathrm{SiO}_{2}$ diagram (Peccerillo and Taylor, 1976) illustrating the 517 compositional diversity of the Lopevi lavas emitted before and after 1960, and the overall 518 dominance of basic compositions for the Vanuatu lavas (small circles: data from Georoc 519 database and from our unpublished data. Triangles are used for data from Handley et al. 
520 (2008). Lopevi lavas plot in the medium-K calc alkaline series with low $\mathrm{K}_{2} \mathrm{O}$ content

521 compared to other Vanuatu lavas.

523 Figure 4: Major element binary diagrams showing the effect of fractional crystallization with 524 crystallization of olivine and clinopyroxene before plagioclase. (a) $\mathrm{MgO}$ and (b) $\mathrm{Al}_{2} \mathrm{O}_{3}$ shown 525 as a function of silica content.

Figure 5: (a) REE patterns of the Lopevi lavas normalized to the chondritic values from

McDonough and Sun (1995). (b) Extended trace elements patterns of Lopevi lavas normalized to the N-MORB values from Sun and McDonough (1989). Only samples measured with the method described by Chauvel et al. (2011) are shown in the extended diagram. Shaded areas correspond to Vanuatu basalts reported by Peate et al. (1997) from islands facing the D’Entrecasteaux Ridge (DER) collision (e.g. Gaua, Aoba, Ambrym).

534 Figure 6: $\mathrm{Nb}$ versus Th diagram showing the behaviour of two highly incompatible elements 535 with similar bulk D values. Pre- (gray line) and post-1960 (black line) lavas display different $536 \mathrm{Th} / \mathrm{Nb}$ ratios.

538 Figure 7: Isotopic diagrams showing the very restricted range of variation of the Lopevi

539 lavas. (a) Nd-Sr isotope diagram. The mantle array is from Hofmann and White (1982). (b)

540 Hf-Nd isotope diagram. The global correlation is from Graham et al. (2006). (c) ${ }^{208} \mathrm{~Pb} /{ }^{204} \mathrm{~Pb}-$ $541{ }^{206} \mathrm{~Pb} /{ }^{204} \mathrm{~Pb}$ and $(\mathrm{d}){ }^{207} \mathrm{~Pb} /{ }^{204} \mathrm{~Pb}-{ }^{206} \mathrm{~Pb} /{ }^{204} \mathrm{~Pb}$ diagrams. The Northern Hemisphere Reference 542 Line is from Hart (1984). The discrimination line is from Pearce et al. (2007) in diagram (b) 543 and from Kempton et al. (2002) in diagram (c). MORB data are from Meyzen et al. (2007), 544 using the East Pacific Rise data for the Pacific MORB and the South East Indian Ridge data 
545 for the Indian MORB (excluding the references from the Australia Antarctica Discordance).

546 NLB AOC: Altered Oceanic Crust from the North Loyalty Basin. NLB Sediments: North

547 Loyalty Basin sediments. NLB data correspond to samples coming from the DSDP Hole 286

548 (Fig. 1) and are from Peate et al. (1997)(for Pb, samples leached), Briqueu et al. (1994)(for

549 Sr-Nd-Pb) and from Pearce et al. (2007)(for Sr-Nd-Hf). Vanuatu data are from Peate et al.

550 (1997), Laporte et al. (1998), Turner et al. (1999), Pearce et al. (2007), and from personal

551 unpublished data.

552

553 Figure 8: (a) ${ }^{87} \mathrm{Sr} /{ }^{86} \mathrm{Sr}$ (b) ${ }^{143} \mathrm{Nd} /{ }^{144} \mathrm{Nd}$ (c) ${ }^{208} \mathrm{~Pb} /{ }^{204} \mathrm{~Pb}$ ratios versus $\mathrm{SiO}_{2}$ wt \% diagrams

554 showing the decrease $(\mathrm{Sr}, \mathrm{Pb})$ and the increase $(\mathrm{Nd})$ of the isotopic ratios during the magmatic

555 differentiation $\left(\mathrm{SiO}_{2}\right.$ as an index of differentiation) due to crustal contamination. $2 \sigma$ represents

556 the mean of the individual analytical error.

557

Figure 9: (a) ${ }^{206} \mathrm{~Pb} /{ }^{204} \mathrm{~Pb}$ vs. $\mathrm{U} / \mathrm{Pb}$ (b) ${ }^{207} \mathrm{~Pb} /{ }^{204} \mathrm{~Pb}$ vs. ${ }^{206} \mathrm{~Pb} /{ }^{204} \mathrm{~Pb}$ (c) ${ }^{176} \mathrm{Hf} /{ }^{177} \mathrm{Hf}$ vs. ${ }^{208} \mathrm{~Pb} /{ }^{204} \mathrm{~Pb}$

559 diagrams showing combined assimilation and fractional crystallization (AFC) models

560 described in the text. The starting end-members are the high MgO basalts LO03 (post-1960)

561 and LO15 (pre-1960). The fraction of melt remaining $(\mathrm{F})$ is indicated on the AFC model

562 curves by tick marks every 0.1 step. Parameters used in the models for the pre- 1960 (gray

563 curve) and the post- 1960 (black curve) are reported in the Table 2.

564

565 Figure 10: ${ }^{87} \mathrm{Sr} /{ }^{86} \mathrm{Sr}$ versus $\mathrm{Ba} / \mathrm{Yb}$ diagram showing the geochemical differences between the 566 pre- and the post-1960 lavas, especially for the less differentiated samples, and the effect of 567 AFC processes (parameters of the model in Table 2). 
569 Figure 11: Extended trace element patterns showing the major differences between the high

$570 \mathrm{MgO}$ basalts LO03, LO04 (post-1960) and LO15 and LO20 (pre-1960). REE in bold

571 characters. Inset: REE patterns normalized to the chondritic values from McDonough and Sun

572 (1995). Boxes indicate elements showing significant difference between the two series.

573

574 Table 1: Major elements are presented on a volatile-free basis to $100 \%$ with total iron as

$575 \mathrm{Fe}_{2} \mathrm{O}_{3}(\mathrm{t})$. Samples ticked with a " $\S$ ” were measured using the protocole developed by Barrat

576 et al. (1996), while the others were measured by the protocole described in Chauvel et al.

577 (2011). LO04 was measured by both protocols and standard deviation (sd) values between the

578 two measurements are given. Sr isotopic data measured on a Finnigan MAT26X for data

579 ticked with a “*”, and on a Thermo Fischer TRITON for others.

580

581 Table 2: AFC model parameters and results of batch melting model. The trace element

582 contents of the contaminant $\left(\mathrm{C}_{\mathrm{a}}\right)$ were calculated from the batch melting $(1 \%$ for the pre-

5831960 group and $10 \%$ for the post- 1960 group) of a metabasalt (source mineralogy: 0.2

584 orthopyroxene, 0.40 clinopyroxene, 0.25 plagioclase, 0.15 amphibole) having the trace

585 element content of an N-MORB from Sun and McDonough (1989). The respective

586 contributions to the melt are 0.4 clinopyroxene, 0.35 amphibole, 0.2 plagioclase, 0.05

587 orthopyroxene. Partition coefficients used to calculate bulk D values are from Adam and

588 Green (2006) and Aignertorres et al. (2007). Partition coefficient of Yb between

589 clinopyroxene and melt is from Green et al. (2000). Partition coefficients of $\mathrm{Pb}$ are from Hauri

590 et al. (1994), Bindeman et al. (1998), and McKenzie and O'Nions (1991). The isotopic ratios

591 of the contaminant $\left(\mathrm{R}_{\mathrm{a}}\right)$ were chosen to fit correctly the data and are consistent with values

592 found in MORB. " $r$ " value used is 0.3 for the post-1960 lavas and 0.2 for the pre-1960 lavas.

$593 \mathrm{D}, \mathrm{Ca}$, and $\mathrm{r}$ are assumed to be constant during the AFC process. The $\mathrm{r}$ value used is as low as 
594

601

602

603

604

605

606

607

608

609

610

611

612

613

614

615

616

617

possible, because a small degree of contamination is easier to invoke. The starting endmembers are the high MgO basalts LO03 (post-1960) and LO15 (pre-1960). Parameters used in the model are slightly different between the pre- and the post-1960 lavas.

\section{References}

Adam, J. and Green, T., 2006. Trace element partitioning between mica- and amphibolebearing garnet lherzolite and hydrous basanitic melt: 1. Experimental results and the investigation of controls on partitioning behaviour. Contributions to Mineralogy and Petrology, 152(1): 1-17.

Aigner-Torres, M., Blundy, J., Ulmer, P. and Pettke, T., 2007. Laser Ablation ICPMS study of trace element partitioning between plagioclase and basaltic melts: an experimental approach. Contributions to Mineralogy and Petrology, 153(6): 647-667.

Andrew, J.E., Packham, G., Eade, J.V., Holdsworth, B.K., Jones, D.L., De Vriesklein, G., Kroenke, L.W., Saito, T., Shafik, S., Stoeser, D.B. and Van Der Lingen, G.J., 1973. Site 285 and 286. In: Andrew, J.E. and Packham, G. (Eds.), Initial reports of the Deep Sea Drilling Project, Washington, DC, United States (USA), pp. 27-131.

Auzende, J.M., Pelletier, B. and Eissen, J.P., 1995. The North Fiji Basin: Geology, Structure and geodynamic evolution. In: Taylor, B. (Ed.), Back-arc basin: tectonics and magmatism, New York, pp. 139-175.

Auzende, J.M., Pelletier, B. and Lafoy, Y., 1994. Twin active spreading ridges in the North Fiji Basin (Southwest Pacific). Geology, 22(1): 63-66. 
618 Baker, P.E. and Condliffe, E., 1996. Compositional variations in submarine volcanic ashes from the vicinity of the Vanuatu island arc: A response to ridge-arc collision? Journal of Volcanology and Geothermal Research, 72(3-4): 225-238.

621 Barrat, J.A., Keller, F., Amosse, J., Taylor, R.N., Nesbitt, R.W. and Hirata, T., 1996. Determination of rare earth elements in sixteen silicate reference samples by ICP-MS after Tm addition and ion exchange separation. Geostandards Newsletter, 20(1): 133139.

Barsdell, M., 1988. Petrology and petrogenesis of clinopyroxene-rich tholeiitic lavas, Merelava volcano, Vanuatu. Journal of Petrology, 29(5): 927-964.

Barsdell, M. and Berry, R.F., 1990. Origin and evolution of primitive island-arc ankaramites from Western Epi, Vanuatu. Journal of Petrology, 31(3): 747-777.

Barsdell, M., Smith, I.E.M. and Spoerli, K.B., 1982. The origin of reversed geochemical zoning in the northern New Hebrides volcanic arc. Contributions to Mineralogy and Petrology, 81(2): 148-155.

Bindeman, I.N., Davis, A.M. and Drake, M.J., 1998. Ion microprobe study of plagioclasebasalt partition experiments at natural concentration levels of trace elements. Geochimica et Cosmochimica Acta, 62(7): 1175-1193.

Brenan, J.M., Shaw, H.F., Ryerson, F.J. and Phinney, D.L., 1995. Mineral-aqueous fluid partitioning of trace-elements at 900 degrees-C and 2.0 gpa - Constraints on the traceelement chemistry of mantle and deep-crustal fluids. Geochimica et Cosmochimica Acta, 59(16): 3331-3350.

Briqueu, L. and Lancelot, J.R., 1983. Sr isotopes and K, Rb, Sr balance in sediments and igneous rocks from the subducted plate of the Vanuatu (New Hebrides) active margin. Geochimica et Cosmochimica Acta, 47: 191-200. 
642 Briqueu, L., Laporte, C., Crawford, A.J., Hasenaka, T., Baker, P.E. and Coltorti, M., 1994.

643

644

645

646

647

648

649

650

651

652

653

654

655

656

657

658

659

660

661

662

663

664

665

666 Temporal magmatic evolution of the Aoba Basin, central New Hebrides island arc; $\mathrm{Pb}$, $\mathrm{Sr}$, and $\mathrm{Nd}$ isotopic evidence for the coexistence of two mantle components beneath the arc. In: Greene, H.G., Collot, J.-Y., Stokking, L.B. et al. (Eds.), Proceedings of the Ocean Drilling Program, Scientific Results, 134, College Station, TX, United States (USA), pp. 393-401.

Bryan, W.B., Finger, L.W. and Chayes, F., 1969. Estimating proportions in petrographic mixing equations by least-squares approximation. Science, 163(3870): 926-927.

Calmant, S., Pelletier, B., Lebellegard, P., Bevis, M., Taylor, F.W. and Phillips, D.A., 2003. New insights on the tectonics along the New Hebrides subduction zone based on GPS results. Journal of Geophysical Research-Solid Earth, 108(B6): 2319-2340.

Châtelain, J.L., Molnar, P., Prévot, R. and Isacks, B., 1992. Detachment of part of the downgoing slab and uplift of the New Hebrides (Vanuatu) islands. Geophysical Research Letters, 19(14): 1507-1510.

Chauvel, C., Bureau, S. and Poggi, C., 2011. Comprehensive Chemical and Isotopic Analyses of Basalt and Sediment Reference Materials. Geostandards and Geoanalytical Research, 35(1): 125-143.

Collot, J.Y., Daniel, J. and Burne, R.V., 1985. Recent tectonics associated with the subduction collision of the d'Entrecasteaux zone in the central New-Hebrides. Tectonophysics, 112(1-4): 325-356.

Crawford, A.J., Briqueu, L., Laporte, C. and Hasenaka, T., 1995. Coexistence of Indian and Pacific oceanic upper mantle reservoirs beneath the central New Hebrides island arc. In: Taylor, B. and Natland, J. (Eds.), Active margins and marginal basins of the western Pacific. Geophysical Monograph. American Geophysical Union, Washington, DC, United States (USA), pp. 199-217. 
DePaolo, D.J., 1981. Trace-element and isotopic effects of combined wallrock assimilation and fractional crystallization. Earth and Planetary Science Letters, 53(2): 189-202.

Dupuy, C., Dostal, J., Marcelot, G., Bougault, H., Joron, J.L. and Treuil, M., 1982. Geochemistry of basalts from central and southern New Hebrides arc - Implication for their source rock composition. Earth and Planetary Science Letters, 60(2): 207-225.

Eggins, S.M., 1993. Origin and differentiation of picritic arc magmas, Ambae (Aoba), Vanuatu. Contributions to Mineralogy and Petrology, 114(1): 79-100.

Eiler, J.M., McInnes, B., Valley, J.W., Graham, C.M. and Stolper, E.M., 1998. Oxygen isotope evidence for slab-derived fluids in the sub-arc mantle. Nature, 393(6687): 777781.

Elliott, T., Plank, T., Zindler, A., White, W. and Bourdon, B., 1997. Element transport from slab to volcanic front at the Mariana arc. Journal of Geophysical Research-Solid Earth, 102(B7): 14991-15019.

Galer, S.J.G. and Abouchami, W., 1998. Practical application of lead triple spiking for correction of instrumental mass discrimination, Goldschmidt conference, Toulouse, pp. 491-492.

Graham, D.W., Blichert-Toft, J., Russo, C.J., Rubin, K.H. and Albarède, F., 2006. Cryptic striations in the upper mantle revealed by hafnium isotopes in southeast Indian ridge basalts. Nature, 440(7081): 199-202.

Green, T.H., Blundy, J.D., Adam, J. and Yaxley, G.M., 2000. SIMS determination of trace element partition coefficients between garnet, clinopyroxene and hydrous basaltic liquids at 2-7.5 GPa and 1080-1200 degrees C. Lithos, 53(3-4): 165-187.

Greene, H.G., Collot, J.-Y., Fisher, M.A. and Crawford, A.J., 1994. Neogene tectonic evolution of the New Hebrides island arc; a review incorporating ODP drilling results. In: Greene, H.G., Collot, J.-Y., Stokking, L.B. and al., e. (Eds.), Proceedings of the 

(USA), pp. 19-46.

694

695

696

697

698

699

700

701

702

703

704

705

706

707

708

709

710

711

712

713

714

Greene, H.G., MacFarlane, A., Johnson, D.P. and Crawford, A.J., 1988. Structure and tectonics of the central New Hebrides arc. In: Greene, H.G. and Wong, F.L. (Eds.), Geology and offshore resources of Pacific Island Arcs - Vanuatu region. Earth Science Series. Circum-Pacific Council for Energy and Mineral Resources, Houston, TX, United States (USA), pp. 377-412.

Grove, T.L., Chatterjee, N., Parman, S.W. and Medard, E., 2006. The influence of H2O on mantle wedge melting. Earth and Planetary Science Letters, 249(1-2): 74-89.

Handley, H.K., Turner, S.P., Smith, I.E.M., Stewart, R.B. and Cronin, S.J., 2008. Rapid timescales of differentiation and evidence for crustal contamination at intra-oceanic arcs: Geochemical and U-Th-Ra-Sr-Nd isotopic constraints from Lopevi Volcano, Vanuatu, SW Pacific. Earth and Planetary Science Letters, 273(1-2): 184-194.

Hart, S.R., 1984. A large-scale isotope anomaly in the Southern-Hemisphere mantle. Nature, 309(5971): 753-757.

Hauri, E.H., Wagner, T.P. and Grove, T.L., 1994. Experimental and natural partitioning of $\mathrm{Th}, \mathrm{U}, \mathrm{Pb}$ and other trace-elements between garnet, clinopyroxene and basaltic melts. Chemical Geology, 117(1-4): 149-166.

Hawkesworth, C.J., Turner, S.P., McDermott, F., Peate, D.W. and vanCalsteren, P., 1997. UTh isotopes in arc magmas: Implications for element transfer from the subducted crust. Science, 276(5312): 551-555.

Hermann, J. and Spandler, C.J., 2008. Sediment melts at sub-arc depths: An experimental study. Journal of Petrology, 49(4): 717-740. 
Heyworth, Z., Knesel, K.M., Turner, S.P. and Arculus, R.J., 2011. Pb-isotopic evidence for rapid trench-parallel mantle flow beneath Vanuatu. Journal of the Geological Society, 168(1): 265-271.

Hildreth, W. and Moorbath, S., 1988. Crustal contributions to arc magmatism in the Andes of Central Chile. Contributions to Mineralogy and Petrology, 98(4): 455-489.

Hofmann, A.W. and White, W.M., 1982. Mantle plume from ancient oceanic-crust. Earth and Planetary Science Letters, 57(2): 421-436.

Huchon, P., Gracia, E., Ruellan, E., Joshima, M. and Auzende, J.M., 1994. Kinematics of active spreading in the central North Fiji Basin (Southwest Pacific). Marine Geology, 116(1-2): 69-87.

Jochum, K.P. and Brueckner, S.M., 2008. Reference Materials in Geoanalytical and Environmental Research - Review for 2006 and 2007. Geostandards and Geoanalytical Research, 32(4): 405-452.

Johnson, M.C. and Plank, T., 1999. Dehydration and melting experiments constrain the fate of subducted sediments. Geochemistry Geophysics Geosystems, 1. http://dx.doi.org/10.1029/1999GC000014

Kempton, P.D., Pearce, J.A., Barry, T.L., Fitton, J.G., Langmuir, C. and Christie, D.M., 2002. $\mathrm{Sr}-\mathrm{Nd}-\mathrm{Pb}-\mathrm{Hf}$ isotope results from ODP Leg 187: Evidence for mantle dynamics of the Australian-Antarctic Discordance and origin of the Indian MORB source. Geochemistry Geophysics Geosystems, 3. http://dx.doi.org/10.1029/2002GC000320

Kessel, R., Schmidt, M.W., Ulmer, P. and Pettke, T., 2005. Trace element signature of subduction-zone fluids, melts and supercritical liquids at 120-180 km depth. Nature, 437(7059): 724-727. 
Langmuir, C.H., Bender, J.F., Bence, A.E., Hanson, G.N. and Taylor, S.R., 1977. Petrogenesis of basalts from Famous area - Mid-Atlantic Ridge. Earth and Planetary Science Letters, 36(1): 133-156.

Laporte, C., Briqueu, L., Cluzel, D. and Eissen, J.P., 1998. Isotopic gradient along the New Hebrides arc (Vanuatu, SW Pacific). Collision of the d'Entrecasteaux Zone and heterogeneity of mantle sources. Comptes Rendus de l'Académie des Sciences Série IIA, 326(2): 101-106.

MacFarlane, A., Carney, J.N., Crawford, A.J. and Greene, H.G., 1988. Vanuatu - A review of the onshore geology. In: Greene, H.G., Wong, F.L. (Ed.), Geology and offshore resources of Pacific Island Arcs - Vanuatu region. Earth Science Series. CircumPacific Council for Energy and Mineral Resources, Houston, TX, United States (USA), pp. 24-68.

Manhès, G., Allègre, C.J. and Provost, A., 1984. U-Th-Pb systematics of the eucrite Juvinas Precise age-determination and evidence for exotic lead. Geochimica et Cosmochimica Acta, 48(11): 2247-2264.

Mann, P. and Taira, A., 2004. Global tectonic significance of the Solomon Islands and Ontong Java Plateau convergent zone. Tectonophysics, 389(3-4): 137-190.

McCulloch, M.T. and Gamble, J.A., 1991. Geochemical and geodynamical constraints on subduction zone magmatism. Earth and Planetary Science Letters, 102(3-4): 358-374.

McDonough, W.F. and Sun, S.S., 1995. The composition of the Earth. Chemical Geology, 120(3-4): 223-253.

McKenzie, D. and O'Nions, R.K., 1991. Partial melt distributions from inversion of RareEarth Element concentrations. Journal of Petrology, 33(6): 1453-1453.

Meffre, S. and Crawford, A.J., 2001. Collision tectonics in the New Hebrides arc (Vanuatu). Island Arc, 10(1): 33-50. 
Métrich, N., Allard, P., Aiuppa, A., Bani, P., Bertagnini, A., Shinohara, H., Parello, F., Di Muro, A., Garaebiti, E., Belhadj, O. and Massare, D., 2011. Magma and Volatile Supply to Post-collapse Volcanism and Block Resurgence in Siwi Caldera (Tanna Island, Vanuatu Arc). Journal of Petrology, 52(6): 1077-1105.

Meyzen, C.M., Blichert-Toft, J., Ludden, J.N., Humler, E., Mevel, C. and Albarède, F., 2007. Isotopic portrayal of the Earth's upper mantle flow field. Nature, 447(7148): 10691074.

Monzier, M., Danyushevsky, L.V., Crawford, A.J., Bellon, H. and Cotten, J., 1993. High-Mg andesites from the southern termination of the New-Hebrides island-arc (SW Pacific). Journal of Volcanology and Geothermal Research, 57(3-4): 193-217.

Monzier, M., Robin, C., Eissen, J.P. and Cotten, J., 1997. Geochemistry vs. seismo-tectonics along the volcanic New Hebrides Central Chain (Southwest Pacific). Journal of Volcanology and Geothermal Research, 78(1-2): 1-29.

Pascal, G., Isacks, B.L., Baranzangi, M. and Dubois, J., 1978. Precise relocalisations of earthquakes and seismotectonics of the New Hebrides island arc. Journal of Geophysical Research, 83: 4957-4973.

Peacock, S.M., 1990. Fluid processes in subduction zones. Science, 248(4953): 329-337.

Pearce, J.A., Kempton, P.D. and Gill, J.B., 2007. Hf-Nd evidence for the origin and distribution of mantle domains in the SW Pacific. Earth and Planetary Science Letters, 260(1-2): p 98-114.

Peate, D.W., Baker, J.A., Jakobsson, S.P., Waight, T.E., Kent, A.J.R., Grassineau, N.V. and Skovgaard, A.C., 2009. Historic magmatism on the Reykjanes Peninsula, Iceland: a snap-shot of melt generation at a ridge segment. Contributions to Mineralogy and Petrology, 157(3): 359-382. 
Peate, D.W., Pearce, J.A., Hawkesworth, C.J., Colley, H., Edwards, C.M.H. and Hirose, K., 1997. Geochemical variations in Vanuatu arc lavas: the role of subducted material and a variable mantle wedge composition. Journal of Petrology, 38(10): 1331-1358.

Peccerillo, A. and Taylor, S.R., 1976. Geochemistry of Eocene calc-alkaline volcanic-rocks from Kastamonu area, Northern Turkey. Contributions to Mineralogy and Petrology, 58(1): 63-81.

Pelletier, B., Calmant, S. and Pillet, R., 1998. Current tectonics of the Tonga New Hebrides region. Earth and Planetary Science Letters, 164(1-2): 263-276.

Picard, C., Monzier, M., Eissen, J.-P. and Robin, C., 1995. Concomitant evolution of tectonic environment and magma geochemistry, Ambrym volcano (Vanuatu, New Hebrides arc). In: Smellie, J.L. (Ed.), Volcanism associated with extension at consuming plate margin. Geological Society of America, Special Publication, pp. 135-154.

Plank, T., 2005. Constraints from thorium/lanthanum on sediment recycling at subduction zones and the evolution of the continents. Journal of Petrology, 46(5): 921-944.

Price, R.C. and Kroenke, L.W., 1991. Tectonics and magma genesis in the northern North Fiji Basin. Marine Geology, 98(2-4): 241-258.

Prouteau, G., Scaillet, B., Pichavant, M. and Maury, R., 2001. Evidence for mantle metasomatism by hydrous silicic melts derived from subducted oceanic crust. Nature, 410(6825): 197-200.

Raos, A.M. and Crawford, A.J., 2004. Basalts from the Efate Island Group, central section of the Vanuatu arc, SW Pacific: geochemistry and petrogenesis. Journal of Volcanology and Geothermal Research, 134(1-2): 35-56.

Richard, P., Shimizu, N. and Allègre, C.J., 1976. Nd143/Nd146 A natural tracer - Application to oceanic basalt. Earth and Planetary Science Letters, 31(2): 269-278. 
Shaw, D.M., 1970. Trace element fractionation during anatexis. Geochimica et Cosmochimica Acta, 34(2): 237-243.

Shimizu, N. and Kushiro, I., 1975. Partitioning of rare-earth elements between garnet and liquid at high-pressures - Preliminary experiments. Geophysical Research Letters, 2(10): 413-416.

Sorbadere, F., Schiano, P., Métrich, N. and Garaebiti, E., 2011. Insights into the origin of primitive silica-undersaturated arc magmas of Aoba volcano (Vanuatu arc). Contributions to Mineralogy and Petrology, 162(5): 995-1009.

Stalder, R., Foley, S.F., Brey, G.P. and Horn, I., 1998. Mineral aqueous fluid partitioning of trace elements at 900-1200 degrees C and 3.0-5.7 GPa: New experimental data for garnet, clinopyroxene, and rutile, and implications for mantle metasomatism. Geochimica et Cosmochimica Acta, 62(10): 1781-1801.

Sun, S.S. and McDonough, W.F., 1989. Chemical and isotopic systematics of oceanic basalts: Implications for mantle composition and processes, Chemical and isotopic systematics of oceanic basalts. Geological Society, London, Special Publications., pp. 313-345.

Tatsumi, Y., 1986. Formation of the volcanic front in subduction zones. Geophysical Research Letters, 13(8): 717-720.

Taylor, F.W., Baevis, M.G., Schutz, B.E., Kuang, D., Recy, J., Calmant, S., Charley, D., Regnier, M., Perin, B., Jackson, M. and Reichenfeld, C., 1995. Geodetic measurements of convergence at the New-Hebrides-island arc indicate arc fragmentation caused by an impinging aseismic ridge. Geology, 23(11): 1011-1014.

Turner, S.P., Peate, D.W., Hawkesworth, C.J., Eggins, S.M. and Crawford, A.J., 1999. Two mantle domains and the time scales of fluid transfer beneath the Vanuatu arc. Geology, 27(11): 963-966. 
835 Warden, A.J., 1967. The 1963-65 eruption of Lopevi Volcano (New Hebrides). Bulletin of $836 \quad$ volcanology, 30: 277-306.

837 White, W.M., Albarède, F. and Telouk, P., 2000. High-precision analysis of $\mathrm{Pb}$ isotope ratios by multi-collector ICP-MS. Chemical Geology, 167(3-4): 257-270.

839 Williams, C.E. and Curtis, R., 1964. The eruption of Lopevi, New Hebrides, July 1960. Bulletin of volcanology, 27: 423-433.

841 Woodhead, J.D., 1989. Geochemistry of the mariana arc (Western Pacific) - Source composition and processes. Chemical Geology, 76(1-2): 1-24.

843 Yang, Y.H., Zhang, H.F., Chu, Z.Y., Xie, L.W. and Wu, F.Y., 2010. Combined chemical separation of $\mathrm{Lu}, \mathrm{Hf}, \mathrm{Rb}, \mathrm{Sr}, \mathrm{Sm}$ and $\mathrm{Nd}$ from a single rock digest and precise and accurate isotope determinations of $\mathrm{Lu}-\mathrm{Hf}, \mathrm{Rb}-\mathrm{Sr}$ and $\mathrm{Sm}-\mathrm{Nd}$ isotope systems using Multi-Collector ICP-MS and TIMS. Int. J. Mass Spectrom., 290(2-3): 120-126. 
Table 1: Isotope ratios, major and trace element content for the Lopevi lavas

\begin{tabular}{|c|c|c|c|c|c|c|c|c|c|c|c|c|c|c|c|c|c|c|c|}
\hline \multirow{5}{*}{$\begin{array}{l}\begin{array}{l}\text { Rock type } \\
\text { Age } \\
\text { Latitude } \\
\text { Longitude }\end{array}\end{array}$} & \multicolumn{12}{|c|}{$\begin{array}{l}\text { Post-1960 lavas } \\
\end{array}$} & \multicolumn{7}{|c|}{$\begin{array}{l}\text { Pre-1960 lavas } \\
\end{array}$} \\
\hline & Lo01 & Lo02 & L003 & Lo04 & Lo05 & Loo6 & L007 & L017 & L025 & Lозо & Lo31 & L035 & Loog & Lo09 & LO10 ${ }^{5}$ & Lo11 & Lo12 $^{\mathrm{s}}$ & Lo13 & Lo1 $4^{5}$ \\
\hline & lava flow & lava fllow & lava flow & lava istet & lava flow & bomb & scoria & lava flow & lava flow & bomb & lava flow & block & lava flow & lava flow & lava flow & pebble & pebble & pebble & pebble \\
\hline & 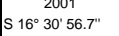 & $\mathrm{S}_{16^{\circ} 30^{\circ} 51.3^{\prime \prime \prime}}$ & 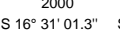 & $\begin{array}{l}19600^{2} \\
\mathrm{~S} 16^{\circ} 30^{\prime} 38.0^{\circ}\end{array}$ & 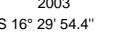 & $\begin{array}{l}\text { popsic-2003 } \\
\text { S16 } 29.97 .9^{\prime \prime}\end{array}$ & 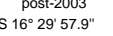 & 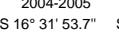 & $516^{2} 3000$ & $\mathrm{~S} 16^{\circ} 30^{\circ} 30.6^{\prime \prime}$ & $S_{1} 6^{\circ} 3000$ & $\begin{array}{l}1968 \text { ? } \\
\text { S16 } 31^{\circ} 05.8^{\prime \prime}\end{array}$ & S16 $16^{\circ} 31^{128.2^{\prime \prime}}$ & s16 $16^{\circ} 31^{2} 29.2^{\prime \prime}$ & $\mathrm{S} 16^{\circ} 31^{\prime} 43.7^{\prime \prime}$ & S $16^{\circ} 31^{1} 43.7^{\prime \prime}$ & S $16^{\circ} 31^{\prime} 43.7^{\prime \prime \prime}$ & S $16^{\circ} 31^{\prime} 43.7^{\prime \prime \prime}$ & S16 $16^{\circ} 1^{1} 43.7^{\prime \prime}$ \\
\hline & E168 & & & & & & $E 168^{\circ} 19^{\prime} 11.6^{\prime \prime}$ & & & & & & $E_{160^{\circ}}^{\circ 19} \cdot 322^{\prime \prime}$ & & & $E 168^{\circ} 19^{9^{2} 28.9^{\prime \prime}}$ & $8^{\circ} 19^{\prime 2} 28.9^{\prime \prime}$ & & $68^{\circ} 19^{2} 28.9^{\prime \prime}$ \\
\hline $\begin{array}{l}w^{4}+\% \\
\mathrm{siO}_{2}\end{array}$ & 52,01 & 50,71 & 49,57 & 49,56 & 50,60 & 50,68 & 50,65 & 51,15 & 51,03 & 51,95 & 52,45 & 53,62 & 50,25 & 50,56 & & 52,10 & 51,86 & 61,37 & 54,26 \\
\hline $\mathrm{TiO}_{2}$ & 0,79 & 0,73 & 0,69 & 0,70 & 0,73 & 0,72 & 0,72 & 0,75 & 0,76 & 0,76 & 0,82 & 0,84 & 0,77 & 0,69 & 0,69 & 0,82 & 0,78 & 0,75 & 0,87 \\
\hline $\begin{array}{lll}\mathrm{Al}_{2} \mathrm{O}_{3} \\
\mathrm{Fen}\end{array}$ & 18,79 & $\begin{array}{l}19,32 \\
0956\end{array}$ & 16,33 & 16,25 & 19,46 & 19,60 & 19,66 & 19,15 & 19,58 & 17,26 & 18,71 & 17,04 & 17,11 & 17,85 & 17,89 & 20,10 & 18,67 & 16,05 & 17,45 \\
\hline $\begin{array}{l}\mathrm{F}_{2} \mathrm{e}_{3} \mathrm{O}_{3}(t) \\
\text { MnO }\end{array}$ & $\begin{array}{l}9,51 \\
0,16\end{array}$ & $\begin{array}{l}9,06 \\
0,16\end{array}$ & $\begin{array}{l}10,48 \\
0,18\end{array}$ & 10,62 & 9,54 & 9,49 & 9,41 & 9,52 & 9,46 & 9,997 & 9,44 & 9, & 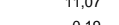 & 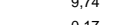 & 9,66 & 9, 935 & 9,49 & 7,53 & 9,91 \\
\hline Mgo & 4,38 & 4,67 & 7.68 & 7,77 & $\begin{array}{l}4,66 \\
4,66\end{array}$ & 4.56 & $\begin{array}{l}4.149 \\
4.49\end{array}$ & 4.58 & 4,41 & $\begin{array}{l}5.179 \\
5.79\end{array}$ & 4.34 & $\begin{array}{ll}4.90 \\
4.90\end{array}$ & 6.16 & $\begin{array}{ll}6.38 \\
6.38\end{array}$ & 6.129 & 324 & 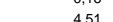 & 246 & 0,177 \\
\hline & & 11.46 & & 11.95 & 11,46 & 11,45 & 11.53 & 11.11 & & 10.48 & 1018 & 9,37 & 1121 & 11,64 & 1156 & 1052 & 1024 & 5.72 & $\begin{array}{l}3.93 \\
889\end{array}$ \\
\hline $\mathrm{Na}_{2} \mathrm{O}$ & $\begin{array}{l}2,74 \\
2,74\end{array}$ & $\begin{array}{l}2,54 \\
2,54\end{array}$ & 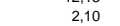 & $\begin{array}{l}2,13 \\
2,13\end{array}$ & $\begin{array}{l}2,54 \\
2.54\end{array}$ & $\begin{array}{l}2,49 \\
2,4\end{array}$ & $\begin{array}{l}2,49 \\
2,49\end{array}$ & 2.61 & $\begin{array}{l}2,58 \\
2,58\end{array}$ & $\begin{array}{l}2,64 \\
2,64\end{array}$ & $\begin{array}{l}2,81 \\
2,81\end{array}$ & 2,96 & $\begin{array}{l}2,46 \\
2,46\end{array}$ & $\begin{array}{l}2,30 \\
2,30\end{array}$ & $\begin{array}{l}2,33 \\
2,33\end{array}$ & $\begin{array}{l}2,92 \\
2,92\end{array}$ & $\begin{array}{l}3,41 \\
3,4\end{array}$ & 3,91 & $\begin{array}{l}8,39 \\
3,33\end{array}$ \\
\hline $\mathrm{K}_{2} \mathrm{O}$ & 0,89 & 0,70 & 0,69 & 0,69 & 0,70 & 0,70 & 0,75 & 0,80 & 0,74 & 0,80 & 0,92 & 1,02 & 0,64 & 0,55 & 0,55 & 0,66 & 0,71 & 1,82 & 1,00 \\
\hline $\mathrm{P}_{2} \mathrm{O}_{5}$ & 0,18 & 0,15 & 0,15 & 0,15 & 0,15 & 0,15 & 0,15 & 0,17 & 0,16 & 0,17 & 0,19 & 0,21 & 0,15 & 0,12 & 0,13 & 0,15 & 0,16 & 0,24 & 0,20 \\
\hline $\begin{array}{l}\text { Lol } \\
\text { Total }\end{array}$ & $\begin{array}{r}-0,42 \\
10,73 \\
\end{array}$ & $\begin{array}{r}-0,043 \\
10,94\end{array}$ & $\begin{array}{r}-0,49 \\
101,05\end{array}$ & $\begin{array}{r}-0,48 \\
10,92\end{array}$ & $\begin{array}{r}-0,48 \\
10,97\end{array}$ & $\begin{array}{l}-0,52 \\
1.00,7\end{array}$ & $\begin{array}{r}-0,39 \\
100,59\end{array}$ & $\begin{array}{r}-0,48 \\
100,95\end{array}$ & $\begin{array}{r}0,01 \\
100,07\end{array}$ & $\begin{array}{r}-0,39 \\
10,69\end{array}$ & $\begin{array}{r}-0,39 \\
1054\end{array}$ & $\begin{array}{r}-0,35 \\
10068\end{array}$ & $\begin{array}{r}-0,50 \\
1072\end{array}$ & $\begin{array}{r}-0,46 \\
1097\end{array}$ & $\begin{array}{l}-0,43 \\
0,04\end{array}$ & $\begin{array}{r}-0,29 \\
1025\end{array}$ & $\begin{array}{r}-0,28 \\
-1010\end{array}$ & $\begin{array}{r}-0,32 \\
1009\end{array}$ & 0,26 \\
\hline ppm & & & & & & & & & & & & 100,086 & $100,1 / 2$ & 100,57 & 100,84 & & 100,04 & 100,08 & \\
\hline $\begin{array}{l}\text { sc } \\
\mathrm{v}\end{array}$ & $\begin{array}{r}29 \\
256\end{array}$ & $\begin{aligned} 29 \\
265\end{aligned}$ & $\begin{array}{r}35 \\
277\end{array}$ & $\begin{array}{r}36 \\
274\end{array}$ & 28 & $\begin{array}{r}30 \\
30 \\
26\end{array}$ & 29 & $\begin{array}{r}30 \\
265\end{array}$ & ${ }^{28}$ & 36 & 27 & 30 & $\begin{array}{r}35 \\
37 \\
270\end{array}$ & 34 & 33 & ${ }^{28} 8$ & 32 & 20 & 27 \\
\hline $\mathrm{cr}$ & ${ }_{28}^{200}$ & ${ }_{26}^{20}$ & 190 & 188 20 & ${ }_{28}^{20}$ & (31 & 年 & ${ }_{34}$ & 17 & $66^{2}$ & 年 & 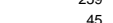 & 4 & 要4 & 年 & . & 20 & 1494 & 265 \\
\hline co & 27 & 29 & 40 & 40 & 29 & 29 & 28 & 29 & 26 & 31 & 23 & 27 & 38 & 33 & 33 & 24 & ${ }_{30}$ & 19 & 28 \\
\hline $\mathrm{Ni}$ & 17 & 17 & 56 & 61 & 19 & 19 & 19 & 20 & 17 & 27 & 16 & 20 & 29 & 36 & 34 & 8 & 16 & 6 & 13 \\
\hline $\mathrm{Cu}$ & 128 & 122 & 115 & 115 & 121 & 135 & 115 & 125 & 114 & ${ }_{99}$ & 106 & 119 & 119 & 120 & 107 & 75 & 97 & 55 & ${ }_{105}$ \\
\hline Ga & 18 & 19 & 16 & 17 & 17 & 19 & 18 & 18 & 18 & 15 & ${ }_{18}^{18}$ & 19 & 18 & 16 & 15 & 19 & 19 & 17 & 18 \\
\hline${ }^{\mathrm{Rb}} \mathrm{b}$ & 15,7 & 12,4 & 12,4 & 12,4 12,4 & 12,1 & 12,2 & 12,0 & 14,3 & 12,6 12,6 & 14,1 & 15,4 & 16,6 & 10,8 & 9.5 & 9,1 & 10,8 & 12,2 & 32,7 & 18,0 \\
\hline y & $\begin{array}{l}230 \\
23.6\end{array}$ & $\begin{array}{l}190 \\
19.9\end{array}$ & $\begin{array}{l}359 \\
17.4\end{array}$ & ${ }_{17.5}$ & 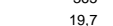 & $\begin{array}{l}368 \\
19.7\end{array}$ & (190 & 年 & 列 & (1) & 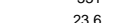 & 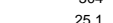 & 204 & (193 & 年 & 列 & 256 & 37. & ${ }^{263}$ \\
\hline $\mathrm{zr}$ & ${ }_{74}^{20.0}$ & ${ }_{56}^{20,0}$ & $\begin{array}{l}2,4,4 \\
47\end{array}$ & $\begin{array}{llll}4,10 \\
49\end{array}$ & $\begin{array}{lll}5.16 \\
56\end{array}$ & $\begin{array}{l}2.17 \\
57\end{array}$ & 然, & 等, & 年, & 68 & ${ }_{76}$ & 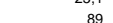 & ${ }_{55}$ & 然, & 52 & 68 & 76 & 159 & $\begin{array}{l}31,1 \\
102\end{array}$ \\
\hline Nb & 1,81 & 1,38 & 1,11 & 1,18 & 1,38 & 1,38 & 1,35 & 1.55 & 1,40 & 1,69 & 1,85 & 2,18 & 1,29 & 1,30 & & & & 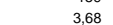 & \\
\hline cs & 0,40 & 0,33 & 0,36 & 0,37 & 0,32 & 0,32 & 0,32 & 0,38 & 0,34 & 0,38 & 0,42 & 0,45 & 0,33 & 0,27 & 0,29 & 0,31 & 0,21 & 0,25 & 0.54 \\
\hline Ba & 164 & 140 & 135 & 138 & 141 & 139 & 138 & 155 & 141 & 159 & 165 & 178 & 126 & 102 & 103 & 114 & 133 & & 169 \\
\hline $\begin{array}{l}\text { La } \\
\text { Ce }\end{array}$ & 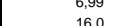 & $\begin{array}{l}5,51 \\
1_{129}\end{array}$ & $\begin{array}{l}4,98 \\
117\end{array}$ & $\begin{array}{l}5,121 \\
{ }_{122}\end{array}$ & $\begin{array}{l}5,50 \\
129\end{array}$ & $\begin{array}{l}5,52 \\
128\end{array}$ & 列 & 6,38 & 5,56 & 6,34 & 7,07 & 7,80 & $\begin{array}{l}4,70 \\
4,70\end{array}$ & $\begin{array}{l}4,57 \\
109\end{array}$ & $\begin{array}{l}4,48 \\
\end{array}$ & 5,15 & 6, 65 & 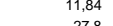 & 8,07 \\
\hline $\mathrm{Pr}$ & 2,34 & $\begin{array}{l}x_{1.90} \\
1.90\end{array}$ & 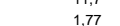 & 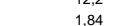 & 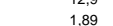 & $\begin{array}{l}2.60 \\
1.90\end{array}$ & 然, & 2,11 & . & 2.14 & 2 & $\begin{array}{l}1,4,4 \\
263\end{array}$ & 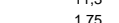 & 157 & 年, & 列, & 作, & 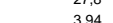 & 18,9 \\
\hline $\mathrm{Nd}$ & 10,9 & 9,1 & 8,7 & 8.9 & 9,0 & 9,0 & 8.8 & 100 & 91 & 102 & 112 & 124 & 86 & 7 & 77 & 90 & 101 & 178 & $\begin{array}{l}2,179 \\
13\end{array}$ \\
\hline Sm & 3,04 & 2,55 & 2,42 & 2,46 & 2.53 & 2,53 & 2,49 & 2,77 & 2.58 & 2,83 & 3,09 & 3,36 & 2,56 & 2,22 & 2,29 & 2,73 & 2,88 & 4,77 & $\begin{array}{l}1,1,0 \\
3,63\end{array}$ \\
\hline Eu & 0,99 & 0,88 & 0,83 & 0,85 & 0,87 & 0,88 & 0,86 & 0,93 & 0,87 & 0,99 & 1,00 & 1,06 & 0,90 & 0,81 & 0,79 & 0,94 & 0,97 & 1,23 & 1,10 \\
\hline$G d$ & 3,52 & 2,97 & 2,79 & 2,84 & 2,96 & 2,95 & 2,87 & 3,20 & 2,91 & 3,34 & 3,54 & 3,82 & 3,09 & 2,74 & 2,78 & 3,43 & 3,56 & 5,20 & 4,27 \\
\hline Div & $\begin{array}{l}0,58 \\
3.39\end{array}$ & $\begin{array}{l}0,50 \\
3.31\end{array}$ & O.4. & $\begin{array}{l}0,46 \\
306\end{array}$ & 0 & 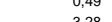 & 0 & 0 & 0 & 0,56 & 0 & 0,63 & 0 & 0 & 0,49 & 0,58 & 0,61 & 0 & 0,74 \\
\hline $\begin{array}{l}\text { Hо } \\
\text { the }\end{array}$ & 0.83 & 0 & 2,63 & 0 & 0 & 0 & 0 & 0 & 0 & 0 & 0.84 & $\begin{array}{l}4,24 \\
0.91\end{array}$ & 0 & 0 & $\begin{array}{l}0,11 \\
07\end{array}$ & $\begin{array}{l}0,000 \\
085\end{array}$ & 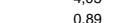 & 128 & $\begin{array}{l}4,80 \\
106\end{array}$ \\
\hline $\mathrm{Er}$ & 2,50 & 2,110 & 1,86 & 1,89 & 2,09 & 2,10 & 2,06 & 2,25 & 2,08 & 2,33 & 2.54 & 2,71 & 2,22 & 2,07 & 2,08 & 2,50 & & 3,90 & $\begin{array}{l}1,00 \\
3,17\end{array}$ \\
\hline $\mathrm{Yb}_{0}$ & $\begin{aligned} 2,40 \\
24\end{aligned}$ & $\begin{array}{l}2,003 \\
2,0\end{array}$ & $\begin{array}{l}1,78 \\
1,1\end{array}$ & $\begin{array}{l}182 \\
182\end{array}$ & 20 & $\begin{array}{l}2,10 \\
201\end{array}$ & $\begin{array}{l}1,198 \\
19\end{array}$ & 2,17 & 203 & 233 & $\begin{array}{l}2,49 \\
249\end{array}$ & 2.62 & 2,15 & 200 & 204 & 249 & 256 & 3.95 & 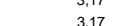 \\
\hline Lu & 0,36 & 0,33 & 0,27 & 0,27 & 0,30 & $\begin{array}{l}0,30 \\
0\end{array}$ & 0,30 & 0,33 & $\begin{array}{l}0,31 \\
0,1\end{array}$ & 0,33 & 0.37 & 0 & 0,32 & 0 & $\begin{array}{l}0,33 \\
0,0\end{array}$ & $0,0,36$ & 0,038 & 0.60 & $\begin{array}{l}0.47 \\
0,47\end{array}$ \\
\hline HH & 2,03 & 1,59 & 1,35 & 1,40 & 1,59 & 1,57 & 1,56 & 1,79 & 1,66 & 1,87 & 2,12 & & 1,56 & 1,41 & & & 2,06 & $\begin{array}{l}4,19 \\
4\end{array}$ & \\
\hline Ta & 0,113 & 0,085 & 0,071 & 0,074 & 0,087 & 0,087 & 0,085 & 0,098 & 0,090 & 0,108 & 0,120 & 0,141 & 0,084 & 0,081 & & & & 0,243 & \\
\hline${ }^{\mathrm{Pb}}$ & $\begin{array}{l}3,16 \\
09\end{array}$ & $\begin{array}{l}2,60 \\
07\end{array}$ & 2,62 & 2,54 & $\begin{array}{l}2,58 \\
077\end{array}$ & 2,62 & 2,76 & 2,96 & $\begin{array}{l}2,79 \\
077\end{array}$ & 1,98 & $\begin{array}{l}1,46 \\
0\end{array}$ & 3,91 & 2,30 & 1,88 & 1,77 & 1,48 & 2,68 & 5,23 & 3,20 \\
\hline Th & 0,91 & 0,72 & 0,62 & 0,64 & 0,71 & 0,71 & 0,71 & 0,83 & 0,77 & 0,88 & 0,95 & 1,02 & 0,54 & 0,58 & 0,59 & 0,61 & 0,78 & 1,92 & 1,08 \\
\hline $\begin{array}{l}\text { Ustopes } \\
\text { sots }\end{array}$ & 0,38 & 0,29 & 0,26 & & 0,29 & 0,29 & 0,29 & 0,34 & 0,32 & 0,35 & 0,39 & 0,45 & 0,24 & 0,22 & 0,23 & 0,27 & 0,33 & 0,88 & 0,49 \\
\hline 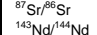 & $\begin{array}{l}0.703970 \pm 11{ }^{\prime} \\
0.5129986\end{array}$ & $\begin{array}{l}0.703996 \pm 8^{*} \\
0.512986 \pm 0\end{array}$ & $\begin{array}{l}0.704035 \pm 9 * \\
0.527295+4\end{array}$ & $\begin{array}{l}0.704085 \pm 8 \\
0.512971 \pm 6\end{array}$ & $\begin{array}{l}0.703969 \pm 9 * \\
0.512968+4\end{array}$ & & & $\begin{array}{l}0.704011 \pm 10 * \\
0.5212061+10\end{array}$ & & & & $0.704012 \pm 8$ & $0.703961 \pm 8^{*}$ & & & & & $0.703937 \pm 8$ & \\
\hline 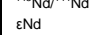 & $\begin{array}{l}0.51298 \pm 6 \\
6,67\end{array}$ & $\begin{array}{l}0.512968 \pm 6 \\
60,44\end{array}$ & $\begin{array}{l}0.512975 \pm 6 \\
6,57\end{array}$ & $\begin{array}{l}0.512971 \pm 6 \\
6,50\end{array}$ & $\begin{array}{l}0.512968 \pm 6 \\
6,44\end{array}$ & & & $\begin{array}{l}0.512961 \pm 10 \\
6.30\end{array}$ & & & & $\begin{array}{l}0.512988 \pm 8 \\
6,79\end{array}$ & $\begin{array}{l}0.512972 \pm 8 \\
6.52\end{array}$ & & & & & & \\
\hline 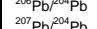 & $\begin{array}{l}18.448 \pm 1 \\
15588 \pm 1\end{array}$ & $\begin{array}{l}18.444 \pm 1 \\
15543+1\end{array}$ & $\begin{array}{l}18.512 \pm 1 \\
15549+1\end{array}$ & $\begin{array}{l}18.508 \pm 1 \\
15.54 \pm\end{array}$ & $18.447 \pm 1$ & & & $18.453 \pm 1$ & & & & $18.471 \pm 1$ & $18.475 \pm 1$ & & & & & $18.514 \pm 1$ & \\
\hline 200 & $\begin{array}{l}15.538 \pm 1 \\
38.379 \pm 3\end{array}$ & $\begin{array}{l}15.543 \pm 1 \\
38.396 \pm 2\end{array}$ & $\begin{array}{l}15.549 \pm 1 \\
38.425 \pm 3\end{array}$ & $\begin{array}{l}155.547 \pm 1 \\
38.422 \pm 3\end{array}$ & $\begin{array}{l}15.542 \pm 1 \\
38397 \pm 2\end{array}$ & & & $\begin{array}{l}15.541 \pm 1 \\
38392 \pm 2\end{array}$ & & & & $\begin{array}{l}15.543 \pm 1 \\
38394+2\end{array}$ & $\begin{array}{l}15.543 \pm 1 \\
38402+3\end{array}$ & & & & & $\begin{array}{l}\begin{array}{l}55.542 \pm 1 \\
38383 \pm 2\end{array}\end{array}$ & \\
\hline${ }^{176} \mathrm{HFf(f^{17 } \mathrm { HF }}$ & $\begin{array}{l}0.283183 \pm 3 \\
14.54\end{array}$ & $\begin{array}{l}0.283179 \pm 4 \\
1440\end{array}$ & $\begin{array}{l}0.283174 \pm 4 \\
1423\end{array}$ & $\begin{array}{l}0.28317 \pm 3 \\
1406 \pm 3\end{array}$ & $\begin{array}{l}0.283157 \pm 10 \\
1360\end{array}$ & & & $\begin{array}{l}0.283184 \pm 4 \\
1458\end{array}$ & & & & $\begin{array}{l}0.283172 \pm 3 \\
1414\end{array}$ & $\begin{array}{l}0.283181 \pm 4 \\
144614\end{array}$ & & & & & $0.283177 \pm 3$ & \\
\hline
\end{tabular}




\begin{tabular}{|c|c|c|c|c|c|c|c|c|c|c|c|c|c|c|c|c|c|c|c|c|c|c|}
\hline \multirow{3}{*}{\begin{tabular}{|l} 
Rock type \\
Age \\
Latitude \\
Longitude \\
\end{tabular}} & \multicolumn{16}{|c|}{$\begin{array}{l}\text { Pre-1960 lavas } \\
\end{array}$} & \multicolumn{4}{|c|}{ Standard } & \multicolumn{2}{|c|}{ Duplicate } \\
\hline & $\begin{array}{l}\text { Lo15 } \\
\text { pebble }\end{array}$ & Lo16 & $\begin{array}{l}\text { Lo18 } \\
\text { pebble }\end{array}$ & $\begin{array}{l}\text { Lo19 }^{8} \\
\text { pebble }\end{array}$ & $\begin{array}{l}\text { Lo20 } \\
\text { lava flow }\end{array}$ & $\begin{array}{l}\text { LO21 }^{\mathrm{s}} \\
\text { lava flow }\end{array}$ & $\begin{array}{l}\text { Lo22 } \\
\text { Lava flow }\end{array}$ & $\begin{array}{l}\text { Lo23 } \\
\text { lava flow }\end{array}$ & $\begin{array}{ll}\text { Lo24 } \\
\text { lava flow }\end{array}$ & $\begin{array}{l}\text { Lo26 } \\
\text { lava flow }\end{array}$ & $\begin{array}{l}\text { Lo2t } \\
\text { lava flow }\end{array}$ & $\begin{array}{l}\text { LO28 } \\
\text { lava flow }\end{array}$ & $\begin{array}{l}\text { Lo2 }^{\text {s }} \\
\text { lava fllow }\end{array}$ & $\begin{array}{l}\text { LO33 }^{\circ} \\
\text { lava flow }\end{array}$ & $\begin{array}{l}\text { Lo34 }^{5} \\
\text { Block }\end{array}$ & L036 & $\begin{array}{c}\text { mean RGM1 } \\
(n=36)\end{array}$ & $\begin{array}{l}\overline{B C R 2}^{3} \\
(n=1)\end{array}$ & 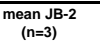 & sd & Loo4 & sd \\
\hline & \multicolumn{22}{|c|}{ 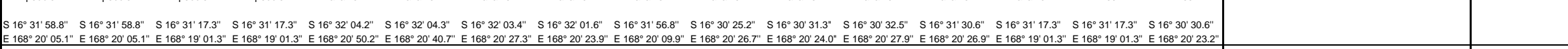 } \\
\hline 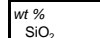 & 49.93 & 56,13 & 61.35 & 52.08 & 50,64 & 52.45 & 52.73 & 51.23 & 52.16 & 52.45 & 55.31 & 50.64 & 52.35 & 52.43 & 52.44 & 54.06 & 73.43 & & & & & \\
\hline $\mathrm{TiO}_{2}$ & $\begin{array}{r}0,70 \\
0,70\end{array}$ & 0,79 & 0,75 & 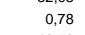 & 0,58 & 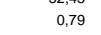 & $\begin{array}{l}0,81 \\
0.10\end{array}$ & 0,81 & 0,78 & $\begin{array}{l}2,40 \\
0,80\end{array}$ & 作6 & $\begin{array}{r}0,74 \\
0,79\end{array}$ & 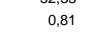 & 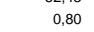 & $\begin{array}{r}0,749 \\
0,79\end{array}$ & $\begin{aligned} 0,84 \\
0,84\end{aligned}$ & 0,27 & & & & & \\
\hline $\mathrm{A}_{2} \mathrm{O}_{3}$ & 16,65 & 17,61 & 16,06 & 18,79 & $\begin{array}{l}16,97 \\
16,9\end{array}$ & 19,75 & 19,45 & 17,37 & 20,36 & 19,00 & 16,96 & 17,30 & 18,70 & 18,73 & $\begin{array}{l}20,09 \\
20,0\end{array}$ & 18,48 & 13,76 & & & & & \\
\hline $\mathrm{Fe}_{2} \mathrm{O}_{3}(\mathrm{t})$ & 10,33 & 8,85 & 7,51 & 9,47 & 9,31 & 9,23 & 9,24 & 10,39 & 9,11 & 9,36 & 8,67 & 10,90 & 9,69 & 9,48 & 9,08 & 9,28 & 1,90 & & & & & \\
\hline $\begin{array}{l}\text { Mno } \\
\text { MaO }\end{array}$ & $\begin{array}{l}0,18 \\
7.50\end{array}$ & $\begin{array}{l}0,16 \\
3.49\end{array}$ & $\begin{array}{l}0,14 \\
2,49\end{array}$ & $\begin{array}{l}0,16 \\
4,74\end{array}$ & $\begin{array}{l}0,16 \\
7,68\end{array}$ & $\begin{array}{l}0,16 \\
3.70\end{array}$ & $\begin{array}{l}0,16 \\
3.72\end{array}$ & $\begin{array}{l}0,18 \\
572\end{array}$ & 0,15 & $\begin{array}{l}0,16 \\
45\end{array}$ & $\begin{array}{l}0,16 \\
5,5\end{array}$ & $\begin{array}{l}0,19 \\
604\end{array}$ & 0,17 & $\begin{array}{l}0,16 \\
463\end{array}$ & $\begin{array}{l}0,16 \\
3.5\end{array}$ & $\begin{array}{l}0,16 \\
3,39\end{array}$ & $\begin{array}{l}0,04 \\
0,29\end{array}$ & & & & & \\
\hline $\begin{array}{l}\mathrm{MgO} \\
\mathrm{CaO}\end{array}$ & $\begin{array}{r}7,50 \\
11,86\end{array}$ & $\begin{array}{l}3,49 \\
8,27\end{array}$ & $\begin{array}{l}2,49 \\
5,72\end{array}$ & $\begin{array}{c}4.74 \\
10.40\end{array}$ & $\begin{array}{r}7,68 \\
12.08\end{array}$ & $\begin{array}{r}3,70 \\
1026\end{array}$ & $\begin{array}{r}3,72 \\
1,016\end{array}$ & $\begin{array}{r}5,72 \\
1099\end{array}$ & $\begin{array}{r}3,43 \\
1043\end{array}$ & $\begin{array}{r}4,51 \\
1090\end{array}$ & 5,15 & $\begin{array}{r}6,04 \\
1055\end{array}$ & $\begin{array}{l}4,32 \\
1016\end{array}$ & $\begin{aligned} 4,63 \\
1090\end{aligned}$ & $\begin{array}{r}3,55 \\
1019\end{array}$ & $\begin{array}{l}3,89 \\
0,03\end{array}$ & 0,29 & & & & & \\
\hline $\begin{array}{l}\mathrm{CaO} \\
\mathrm{Na}_{2} \mathrm{O}\end{array}$ & $\begin{array}{r}\begin{array}{r}11,86 \\
2,18\end{array} \\
\end{array}$ & $\begin{array}{l}8,27 \\
3,32\end{array}$ & $\begin{array}{l}5,72 \\
3,92 \\
\end{array}$ & $\begin{array}{l}\begin{array}{l}10,40 \\
2,77\end{array} \\
-\end{array}$ & $\begin{array}{r}\begin{array}{r}12,08 \\
2,05\end{array} \\
-\end{array}$ & $\begin{array}{l}1026 \\
2,79\end{array}$ & $\begin{array}{l}{ }_{10,16}, 16 \\
2,81\end{array}$ & $\begin{array}{l}{ }^{10,99} \\
2,49\end{array}$ & $\begin{array}{l}\begin{array}{r}10,43 \\
2,79\end{array} \\
\end{array}$ & $\begin{array}{l}10,09 \\
2,79\end{array}$ & $\begin{array}{l}9,02 \\
2,85\end{array}$ & $\begin{array}{l}1,0.55 \\
2,49\end{array}$ & $\begin{array}{l}10,16 \\
2,80\end{array}$ & $\begin{array}{l}10,09 \\
2,81\end{array}$ & $\begin{array}{l}10,19 \\
2,89\end{array}$ & $\begin{array}{l}9,03 \\
3,14\end{array}$ & $\begin{array}{l}1,19 \\
4,10\end{array}$ & & & & & \\
\hline $\mathrm{K}_{2} \mathrm{O}$ & $\begin{array}{l}1,10 \\
0,53 \\
0\end{array}$ & $\begin{array}{l}0.1,18 \\
1,18\end{array}$ & 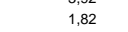 & 0,66 & 0 & 0,72 & 0 & $\begin{array}{l}0,67 \\
0,67\end{array}$ & 0,64 & $\begin{array}{l}0,69 \\
0,69\end{array}$ & $\begin{array}{l}2,05 \\
1,05\end{array}$ & $\begin{array}{l}2,456 \\
0,66\end{array}$ & $\begin{array}{l}2,00 \\
0,83\end{array}$ & $\begin{array}{l}2,012 \\
0,71\end{array}$ & $\begin{array}{l}0,0,66 \\
0,66\end{array}$ & $\begin{array}{l}0,14 \\
0,92\end{array}$ & $\begin{array}{l}4,35 \\
4,35\end{array}$ & & & & & \\
\hline $\mathrm{P}_{2} \mathrm{O}_{5}$ & 0,13 & 0,20 & 0,24 & 0,15 & 0,11 & 0,16 & 0,16 & 0,15 & 0,15 & 0,16 & 0,16 & 0,15 & 0,18 & 0,16 & 0,15 & 0,19 & 0,05 & & & & & \\
\hline$\underset{\substack{\text { loi } \\
\text { Total }}}{ }$ & $\begin{array}{r}-0,44 \\
-1016\end{array}$ & $\begin{array}{r}-0,24 \\
-10075\end{array}$ & $\begin{array}{l}-0,34 \\
008\end{array}$ & $\begin{array}{r}-0,28 \\
-1006\end{array}$ & $\begin{array}{r}-0,25 \\
.1079\end{array}$ & $\begin{array}{r}-0,29 \\
.10636\end{array}$ & $\begin{array}{r}-0,34 \\
.096\end{array}$ & $\begin{array}{r}-0,40 \\
-1007\end{array}$ & $\begin{array}{c}-0,30 \\
1008\end{array}$ & $\begin{array}{r}-0,10 \\
-1009\end{array}$ & $\begin{array}{l}-0,28 \\
0.995\end{array}$ & $\begin{array}{r}-0,32 \\
10038\end{array}$ & $-0,12$ & $\begin{array}{r}-0,17 \\
-1007\end{array}$ & $\begin{array}{l}-0,44 \\
0,17\end{array}$ & $\begin{array}{r}-0,37 \\
-1027\end{array}$ & 0.93 & & & & & \\
\hline ppm & & & & 100,63 & & 100,63 & 100,61 & 100,75 & 100,8 & 100,49 & 99,95 & 100,38 & 100,02 & 100,37 & 100,07 & 100,92 & 100,31 & & & & & \\
\hline sc & $\begin{array}{r}34 \\
271\end{array}$ & $\begin{array}{r}27 \\
226\end{array}$ & $\begin{array}{r}18 \\
146\end{array}$ & $\begin{array}{r}30 \\
267\end{array}$ & $\begin{array}{r}39 \\
243\end{array}$ & $\begin{array}{r}29 \\
255\end{array}$ & $\begin{array}{r}28 \\
262\end{array}$ & $\begin{array}{r}32 \\
226\end{array}$ & $\begin{array}{r}28 \\
265\end{array}$ & $\begin{array}{r}28 \\
269\end{array}$ & $\begin{array}{r}33 \\
209\end{array}$ & $\begin{array}{r}35 \\
287 \\
287\end{array}$ & $\begin{array}{r}29 \\
267\end{array}$ & $\begin{array}{r}29 \\
265\end{array}$ & $\begin{array}{r}29 \\
280\end{array}$ & $\begin{array}{r}27 \\
261\end{array}$ & $\begin{array}{l}3,8 \\
15\end{array}$ & & & & & \\
\hline $\mathrm{cr}_{\mathrm{r}}$ & 144 & $\begin{array}{r}110 \\
9\end{array}$ & $\begin{array}{r}140 \\
5\end{array}$ & 32 & 131 & $\begin{array}{r}253 \\
8\end{array}$ & $\begin{array}{r}202 \\
9\end{array}$ & 42 & $\begin{array}{r}203 \\
2\end{array}$ & $\begin{array}{r}269 \\
25\end{array}$ & $\begin{array}{r}209 \\
87\end{array}$ & $\begin{array}{r}287 \\
41\end{array}$ & $\begin{array}{l}267 \\
14\end{array}$ & $\begin{array}{r}265 \\
23\end{array}$ & $\begin{array}{c}280 \\
0,2\end{array}$ & $\begin{aligned} 261 \\
7\end{aligned}$ & $\begin{array}{l}15 \\
2.7\end{array}$ & & & & & \\
\hline co & 41 & 24 & 19 & 30 & 40 & 26 & 26 & 35 & 24 & 27 & 27 & 35 & 28 & 28 & 25 & 24 & 1,2 & & & & & \\
\hline $\mathrm{Ni}$ & $\begin{array}{l}49 \\
1\end{array}$ & 11 & 7 & 19 & 51 & 10 & 9 & 26 & 8 & 14 & 32 & 30 & 12 & 16 & 8 & 9 & 3,2 & & & & & \\
\hline $\begin{array}{c}\text { Cu } \\
\text { Ga }\end{array}$ & $\begin{array}{l}119 \\
16\end{array}$ & $\begin{array}{l}91 \\
18\end{array}$ & $\begin{array}{l}46 \\
18\end{array}$ & $\begin{array}{l}100 \\
18\end{array}$ & $\begin{array}{l}92 \\
15\end{array}$ & $\begin{array}{c}96 \\
18\end{array}$ & $\begin{array}{c}105 \\
18\end{array}$ & $\begin{array}{l}101 \\
17\end{array}$ & $\begin{array}{l}74 \\
19\end{array}$ & $\begin{array}{l}81 \\
18\end{array}$ & $\begin{array}{l}92 \\
16\end{array}$ & $\begin{array}{l}82 \\
16\end{array}$ & 104 & $\begin{array}{l}61 \\
17\end{array}$ & $\begin{array}{l}91 \\
19\end{array}$ & $\begin{array}{l}84 \\
18\end{array}$ & $\begin{array}{l}15 \\
16\end{array}$ & & & & & \\
\hline $\begin{array}{l}\text { Ga } \\
\text { Rb }\end{array}$ & $\begin{array}{l}16 \\
9,5\end{array}$ & $\begin{array}{r}18 \\
20,9\end{array}$ & $\begin{array}{r}18 \\
32,2\end{array}$ & $\begin{array}{r}18 \\
8.4\end{array}$ & $\begin{array}{r}15 \\
76\end{array}$ & $\begin{array}{r}18 \\
124\end{array}$ & $\begin{array}{r}18 \\
129\end{array}$ & $\begin{array}{r}17 \\
115\end{array}$ & $\begin{array}{r}19 \\
113\end{array}$ & $\begin{array}{r}18 \\
118\end{array}$ & $\begin{array}{r}16 \\
183\end{array}$ & $\begin{array}{r}16 \\
104\end{array}$ & $\begin{array}{r}17 \\
135\end{array}$ & $\begin{array}{r}17 \\
113\end{array}$ & $\begin{array}{r}19 \\
107\end{array}$ & $\begin{array}{r}18 \\
163\end{array}$ & & & & & & \\
\hline $\begin{array}{l}\mathrm{Rb} \\
\mathrm{Sr}\end{array}$ & $\begin{array}{r}9,5 \\
288\end{array}$ & $\begin{array}{l}20,9 \\
254\end{array}$ & $\begin{array}{l}\begin{array}{l}22,2 \\
222\end{array} \\
2\end{array}$ & $\begin{array}{l}8,4 \\
262\end{array}$ & $\begin{array}{l}1,6 \\
240\end{array}$ & $\begin{array}{l}12,4 \\
299\end{array}$ & $\begin{array}{l}12,9 \\
290\end{array}$ & $\begin{array}{l}11,5 \\
299\end{array}$ & $\begin{array}{l}\begin{array}{l}11,3 \\
298\end{array} \\
2\end{array}$ & $\begin{array}{l}11,8 \\
275\end{array}$ & $\begin{array}{l}18,3 \\
244\end{array}$ & $\begin{array}{l}10,4 \\
307\end{array}$ & $\begin{array}{l}13,5 \\
315\end{array}$ & $\begin{array}{l}11,3 \\
271\end{array}$ & $\begin{array}{l}10,7 \\
289\end{array}$ & $\begin{array}{l}16,3 \\
300\end{array}$ & & $\begin{array}{l}\begin{array}{r}48,0 \\
359\end{array}\end{array}$ & $\begin{array}{l}6,2 \\
180\end{array}$ & $\begin{array}{r}0,18 \\
1\end{array}$ & $\begin{array}{l}12,3 \\
353\end{array}$ & $\begin{array}{l}0,1 \\
5\end{array}$ \\
\hline Y & $\begin{array}{l}288 \\
18,6\end{array}$ & $\begin{array}{l}594 \\
29,2\end{array}$ & $\begin{array}{c}225 \\
36,9\end{array}$ & $\begin{array}{l}202 \\
23,8\end{array}$ & $\begin{array}{l}450 \\
15,4\end{array}$ & $\begin{array}{l}249 \\
24,4\end{array}$ & $\begin{array}{l}290 \\
22,9\end{array}$ & $\begin{array}{r}2399 \\
23,8\end{array}$ & $\begin{array}{l}238 \\
23,6\end{array}$ & $\begin{array}{l}24,3 \\
24,3\end{array}$ & $\begin{array}{r}274 \\
27,2\end{array}$ & $\begin{array}{l}307 \\
21,6\end{array}$ & $\begin{array}{l}2415 \\
24,0\end{array}$ & 24,1 & $\begin{array}{l}289 \\
23,1\end{array}$ & $\begin{array}{l}300 \\
25,8\end{array}$ & & $\begin{array}{r}4099 \\
40,0\end{array}$ & $\begin{array}{l}2400 \\
24,0\end{array}$ & 0,2 & $\begin{array}{r}353 \\
18,4\end{array}$ & $\begin{array}{r}0,6 \\
0,6\end{array}$ \\
\hline $\mathrm{zr}$ & $\begin{array}{r}48 \\
\end{array}$ & $\begin{array}{l}106 \\
106\end{array}$ & 157 & 68 & 41 & 67 & 66 & 65 & 65 & 68 & 91 & 55 & 74 & 62 & 62 & 83 & & 183 & 47 & 0,3 & 52 & 2,2 \\
\hline $\begin{array}{l}\mathrm{Nb} \\
\mathrm{CS}\end{array}$ & 1,17 & $\begin{array}{l}2,46 \\
505\end{array}$ & 3,65 & & 1,01 & 037 & 1,74 & & & & & 1,31 & & & & $\begin{array}{l}2,02 \\
, 02\end{array}$ & & & 0,48 & 0,01 & & \\
\hline $\begin{array}{l}\mathrm{Cs} \\
\mathrm{Ba}\end{array}$ & $\begin{array}{l}0,31 \\
97\end{array}$ & $\begin{array}{c}0,53 \\
177\end{array}$ & $\begin{array}{l}0,22 \\
{ }_{25251}\end{array}$ & $\begin{array}{l}0,18 \\
120\end{array}$ & $\begin{array}{r}0,24 \\
75\end{array}$ & $\begin{array}{l}0,37 \\
123\end{array}$ & $\begin{array}{l}0,35 \\
{ }_{12}\end{array}$ & $\begin{array}{c}0,36 \\
14\end{array}$ & $\begin{array}{l}0,32 \\
116\end{array}$ & $\begin{array}{l}0,35 \\
117\end{array}$ & $\begin{array}{l}0,53 \\
161\end{array}$ & $\begin{array}{l}0,32 \\
126\end{array}$ & $\begin{array}{l}0,49 \\
104\end{array}$ & $\begin{array}{l}0,12 \\
122\end{array}$ & $\begin{array}{l}0,15 \\
116\end{array}$ & $\begin{array}{l}0,39 \\
149\end{array}$ & & $\begin{array}{l}1,33 \\
730\end{array}$ & $\begin{array}{l}0,82 \\
2,218\end{array}$ & 0,005 & $\begin{array}{l}0,40 \\
\quad 15\end{array}$ & $\begin{array}{r}0,025 \\
2\end{array}$ \\
\hline $\begin{array}{l}\text { Ba } \\
\text { La }\end{array}$ & $\begin{array}{r}97 \\
4,37\end{array}$ & $\begin{array}{l}177 \\
8,44\end{array}$ & $\begin{array}{r}251 \\
11,97\end{array}$ & $\begin{array}{l}120 \\
5,65\end{array}$ & $\begin{array}{r}75 \\
4,10\end{array}$ & $\begin{array}{c}123 \\
5,76\end{array}$ & $\begin{array}{l}127 \\
5,85\end{array}$ & $\begin{array}{l}134 \\
5,25\end{array}$ & $\begin{array}{c}116 \\
5,37\end{array}$ & $\begin{array}{c}127 \\
5,84\end{array}$ & $\begin{array}{l}161 \\
7,18\end{array}$ & $\begin{array}{l}126 \\
4.76\end{array}$ & $\begin{array}{c}110 \\
6,16\end{array}$ & $\begin{array}{c}122 \\
5,82\end{array}$ & $\begin{array}{l}116 \\
5,37\end{array}$ & $\begin{array}{l}\begin{array}{l}147 \\
7,06\end{array} \\
\text { ? }\end{array}$ & & $\begin{array}{l}700 \\
25,5\end{array}$ & $\begin{array}{l}218 \\
2.25\end{array}$ & $\begin{array}{r}2 \\
0,03\end{array}$ & $\begin{array}{l}\begin{array}{l}135 \\
5,18\end{array} \\
\text { ? }\end{array}$ & $\begin{array}{r}2 \\
0,02\end{array}$ \\
\hline Ce & $\begin{array}{l}4,07 \\
10,8\end{array}$ & $\begin{array}{l}0,44 \\
19,7\end{array}$ & $\begin{array}{r}11,97,3 \\
\end{array}$ & $\begin{array}{l}5,00 \\
13,2\end{array}$ & $\begin{array}{l}4,10 \\
10,0\end{array}$ & $\begin{array}{l}0,10 \\
13,5\end{array}$ & $\begin{array}{l}5,03 \\
14,0\end{array}$ & $\begin{array}{l}\text {, } 250 \\
12,5\end{array}$ & $\begin{array}{l}3,17 \\
12,7\end{array}$ & $\begin{array}{l}5,04 \\
13,7\end{array}$ & $\begin{array}{l}\text { i, } \\
16.5\end{array}$ & 竞, & $\begin{array}{l}0,10 \\
14,9\end{array}$ & $\begin{array}{l}5,02 \\
13,8\end{array}$ & 年 & $\begin{array}{l}1,10.5 \\
16.5\end{array}$ & & 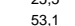 & $\begin{array}{l}2,25 \\
6,5\end{array}$ & $\begin{array}{l}0,033 \\
0.05\end{array}$ & 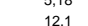 & $\begin{array}{r}0,02 \\
0,1\end{array}$ \\
\hline $\begin{array}{l}\text { Pr } \\
\text { Pr }\end{array}$ & $\begin{array}{l}1,8 \\
1,60\end{array}$ & 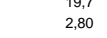 & $\begin{array}{l}\text { tr, } \\
3,92\end{array}$ & $\begin{array}{l}1,2 \\
1,92\end{array}$ & $\begin{array}{l}1,0 \\
1,48\end{array}$ & $\begin{array}{l}1,5 \\
2,00\end{array}$ & $\begin{array}{l}14,0 \\
2,05\end{array}$ & 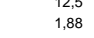 & $\begin{array}{l}1,1 \\
1,88\end{array}$ & $\begin{array}{l}13,1 \\
2,00\end{array}$ & $\begin{array}{l}1,5 \\
2,41\end{array}$ & $\begin{array}{l}1,5 \\
1,75\end{array}$ & $\begin{array}{l}14,9 \\
2,17\end{array}$ & $\begin{array}{l}1,8 \\
1,99\end{array}$ & $\begin{array}{l}13,0 \\
1,89\end{array}$ & $\begin{array}{l}10,5 \\
2,43\end{array}$ & & $\begin{array}{l}5,1 \\
7,04\end{array}$ & $\begin{array}{l}\text {, } 5 \\
1,14\end{array}$ & $\begin{array}{l}0,050 \\
0,005\end{array}$ & $\begin{array}{l}1,1 \\
1,82\end{array}$ & $\begin{array}{l}0,1 \\
0,01\end{array}$ \\
\hline $\begin{array}{l}\mathrm{Nd} \\
\mathrm{sm}\end{array}$ & $\begin{array}{r}8,0 \\
236\end{array}$ & $\begin{array}{l}13,0 \\
360\end{array}$ & $\begin{array}{l}17,5 \\
4.63\end{array}$ & $\begin{array}{r}9,3 \\
2,68\end{array}$ & $\begin{array}{r}7,2 \\
203\end{array}$ & $\begin{array}{r}9,6 \\
273\end{array}$ & $\begin{array}{r}9,9 \\
280\end{array}$ & & $\begin{array}{r}9,1 \\
262\end{array}$ & $\begin{array}{r}9,8 \\
274\end{array}$ & $\begin{array}{l}11,2 \\
310\end{array}$ & $\begin{array}{r}8,8 \\
261\end{array}$ & & & & $\begin{array}{l}11,6 \\
3_{3,21}\end{array}$ & & $\begin{array}{l}28,8 \\
6.58\end{array}$ & $\begin{array}{r}6,4 \\
2,28\end{array}$ & $\begin{array}{l}0,06 \\
0,01\end{array}$ & $\begin{array}{r}8,7 \\
2.47\end{array}$ & $\begin{array}{l}0,15 \\
0,0\end{array}$ \\
\hline $\begin{array}{l}\text { Sm } \\
\text { Eu }\end{array}$ & $\begin{array}{l}2,36 \\
0,85\end{array}$ & $\begin{array}{l}3,60 \\
1,08\end{array}$ & $\begin{array}{l}4,63 \\
1,22\end{array}$ & $\begin{array}{l}2,68 \\
0,91\end{array}$ & $\begin{array}{l}2,03 \\
0,73\end{array}$ & $\begin{array}{l}2,73 \\
0.95\end{array}$ & $\begin{array}{l}2,80 \\
0,94\end{array}$ & $\begin{array}{l}2,70 \\
0.92\end{array}$ & $\begin{array}{l}2,662 \\
0.91\end{array}$ & $\begin{array}{l}2,74 \\
0.90\end{array}$ & $\begin{array}{l}3,100 \\
0.86\end{array}$ & $\begin{array}{l}2,61 \\
0,93\end{array}$ & $\begin{array}{l}2,99 \\
102\end{array}$ & $\begin{array}{l}2,76 \\
0,88\end{array}$ & $\begin{array}{l}2,65 \\
0.92\end{array}$ & $\begin{array}{l}3,21 \\
1,04\end{array}$ & & $\begin{array}{l}6,58 \\
1,88\end{array}$ & $\begin{array}{l}2,28 \\
0.85\end{array}$ & $\begin{array}{c}0,01 \\
0,003\end{array}$ & $\begin{array}{l}2,47 \\
0,85\end{array}$ & $\begin{array}{r}0,01 \\
0,004\end{array}$ \\
\hline$G d$ & $\begin{array}{l}\text { 2, } \\
2,80\end{array}$ & $\begin{array}{l}1,00 \\
4,16\end{array}$ & $\begin{array}{l}1,126 \\
5,18\end{array}$ & $\begin{array}{l}3,91 \\
3,32\end{array}$ & $\begin{array}{l}2,15 \\
2,39\end{array}$ & 3, & 3, & $\begin{array}{l}0,92 \\
3,29\end{array}$ & $\begin{array}{l}0,91 \\
3,21\end{array}$ & $\begin{array}{l}0,90 \\
3,48\end{array}$ & $\begin{array}{l}0,86 \\
3,70\end{array}$ & $\begin{array}{l}0,93 \\
3,17\end{array}$ & $\begin{array}{l}1,02 \\
3,55\end{array}$ & $\begin{array}{l}0,88 \\
3,54\end{array}$ & $\begin{array}{l}0,92 \\
3,41\end{array}$ & $\begin{array}{l}1,04 \\
3,75\end{array}$ & & $\begin{array}{l}1,88 \\
6,89\end{array}$ & $\begin{array}{l}0.85 \\
3,16\end{array}$ & $\begin{array}{l}0,003 \\
0,01\end{array}$ & $\begin{array}{l}0,85 \\
2,81\end{array}$ & $\begin{array}{l}0,004 \\
0,02\end{array}$ \\
\hline Tb & 0,47 & 0,71 & 0,88 & 0,58 & 0,40 & & 0,57 & 0,57 & 0,56 & 0,58 & & 0,54 & 0,63 & 0,60 & 0,60 & 0,63 & & $\begin{array}{l}1,07 \\
1,07\end{array}$ & $\begin{array}{l}3,10 \\
0,57\end{array}$ & & $\begin{array}{l}2,81 \\
0,47\end{array}$ & 0,006 \\
\hline $\begin{array}{l}\mathrm{D}^{\mathrm{D}} \\
\text { Ho }\end{array}$ & $\begin{array}{l}3,17 \\
067\end{array}$ & $\begin{array}{l}4,72 \\
102\end{array}$ & $\begin{array}{l}5,91 \\
127\end{array}$ & $\begin{array}{l}3,82 \\
0.83\end{array}$ & $\begin{array}{l}2,69 \\
0,58\end{array}$ & $\begin{array}{l}3,78 \\
0.83\end{array}$ & 3,81 & 3,73 & 3,66 & $\begin{array}{l}4,01 \\
0,84\end{array}$ & $\begin{array}{l}4,10 \\
0.92\end{array}$ & $\begin{array}{l}3,57 \\
0.07\end{array}$ & $\begin{array}{l}4,08 \\
0,87\end{array}$ & $\begin{array}{l}3,70 \\
0.88\end{array}$ & 3,78 & 4,25 & & 6,36 & 3,99 & 0,02 & 2,99 & 0,05 \\
\hline $\begin{array}{l}{ }^{H} \mathrm{o} \\
\mathrm{H}\end{array}$ & $\begin{array}{l}0,67 \\
207\end{array}$ & $\begin{array}{l}1,02 \\
3,10\end{array}$ & $\begin{array}{l}1,27 \\
386\end{array}$ & 0.83 & $\begin{array}{l}0,58 \\
173\end{array}$ & $0,0,83$ & 0,82 & $\begin{array}{l}0,82 \\
236\end{array}$ & $\begin{array}{l}0,81 \\
235\end{array}$ & $\begin{array}{l}0,84 \\
2,47\end{array}$ & $\begin{array}{l}0,92 \\
270\end{array}$ & $\begin{array}{l}0,77 \\
2,29\end{array}$ & $\begin{array}{l}0,87 \\
253\end{array}$ & 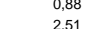 & $\begin{array}{l}0,84 \\
2,47\end{array}$ & $\begin{array}{l}0,91 \\
2774\end{array}$ & & $\begin{array}{l}1,33 \\
3,35\end{array}$ & 0,87 & 0,007 & 0,67 & 0,015 \\
\hline $\begin{array}{l}\mathrm{E} r \\
\mathrm{Yr}\end{array}$ & $\begin{array}{l}2,01 \\
1,91\end{array}$ & $\begin{array}{l}3,10 \\
3,06\end{array}$ & $\begin{array}{l}3,86 \\
3,92\end{array}$ & $\begin{array}{l}2,44 \\
2,42\end{array}$ & $\begin{array}{l}1,73 \\
1,66\end{array}$ & $\begin{array}{l}2,43 \\
237\end{array}$ & $\begin{array}{l}2,47 \\
2,40\end{array}$ & $\begin{array}{l}2,36 \\
2,29\end{array}$ & 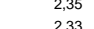 & $\begin{array}{l}2,47 \\
2,48\end{array}$ & $\begin{array}{l}2,70 \\
2,80\end{array}$ & $\begin{array}{l}2,29 \\
2,19\end{array}$ & $\begin{aligned} 2,53 \\
2,43\end{aligned}$ & $\begin{array}{l}2,51 \\
2,55\end{array}$ & $\begin{array}{l}2,47 \\
2,45\end{array}$ & $\begin{array}{l}2,74 \\
2,69\end{array}$ & & $\begin{array}{l}3,75 \\
3,48\end{array}$ & $\begin{array}{l}2,60 \\
2,54\end{array}$ & 0,02 & 1,94 & $\begin{array}{r}0,03 \\
0,005\end{array}$ \\
\hline Lu & $\begin{array}{l},, 11 \\
0,29\end{array}$ & 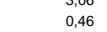 & $\begin{array}{l}3, y 2 \\
0,60\end{array}$ & $\begin{array}{l}2,42 \\
0,36\end{array}$ & $\begin{array}{l}1,106 \\
0,25\end{array}$ & $\begin{array}{l}2,17 \\
0,36\end{array}$ & $\begin{array}{l}2,40 \\
0,37\end{array}$ & $\begin{array}{l}2,9 \\
0,34\end{array}$ & $\begin{array}{l}2,35 \\
0,35\end{array}$ & $\begin{array}{l}2,48 \\
0,37\end{array}$ & $\begin{array}{l}2,80 \\
0,42\end{array}$ & $\begin{array}{l}2,19 \\
0,33\end{array}$ & $\begin{array}{l}2,43 \\
0,33\end{array}$ & $\begin{array}{l}2,55 \\
0,38\end{array}$ & $\begin{array}{l}2,45 \\
0,38\end{array}$ & $\begin{array}{l}2,099 \\
0,41\end{array}$ & & $\begin{array}{l}\begin{array}{l}3,48 \\
0,49\end{array} \\
0\end{array}$ & $\begin{array}{l}2,54 \\
0.38\end{array}$ & $\begin{array}{r}0,022 \\
0,003\end{array}$ & $\begin{array}{l}1,83 \\
0,27\end{array}$ & 0 \\
\hline $\mathrm{HF}$ & 1,39 & 2,85 & 4,12 & & 1,24 & & 1,88 & & & & & 1,58 & & & & 2,26 & & & 1,47 & 0,01 & & \\
\hline Ta & 0,074 & 0,160 & 0,241 & & 0,064 & & 0,110 & & & & & 0,084 & & & & 0,132 & & & 0,039 & 0,0004 & & \\
\hline Pb & $\begin{array}{l}2,29 \\
0.55\end{array}$ & 3,68 & $\begin{array}{l}4,49 \\
0,0\end{array}$ & 2,00 & 1,96 & 2,3 & $\begin{array}{l}2,62 \\
074\end{array}$ & $\begin{array}{l}2,32 \\
\end{array}$ & 2,12 & $\begin{array}{l}2,24 \\
203\end{array}$ & $\begin{array}{l}3,26 \\
1,26\end{array}$ & $\begin{array}{l}2,13 \\
0554\end{array}$ & $\begin{array}{r}2,53 \\
\end{array}$ & $\begin{array}{l}1,41 \\
075\end{array}$ & 2,21 & $\begin{array}{l}3,07 \\
0.07\end{array}$ & & $\begin{array}{l}9,84 \\
559\end{array}$ & 5,18 & ${ }^{0,04}$ & 2,41 & ${ }^{0,09}$ \\
\hline$u_{u}^{\text {Th }}$ & $\begin{array}{l}0.51 \\
0.21\end{array}$ & $\begin{array}{l}1,16 \\
0,53\end{array}$ & $\begin{array}{l}1,92 \\
0,088\end{array}$ & $\begin{array}{l}0,73 \\
0,30\end{array}$ & $\begin{array}{l}0,46 \\
0.19\end{array}$ & $\begin{array}{l}0,68 \\
0,29\end{array}$ & $\begin{array}{l}0,74 \\
0.32 \\
0.32\end{array}$ & $\begin{array}{l}0,58 \\
0,25\end{array}$ & $\begin{array}{l}0,61 \\
0,27\end{array}$ & $\begin{array}{l}0,82 \\
0.32\end{array}$ & $\begin{array}{l}1,12 \\
0,51\end{array}$ & $\begin{array}{l}0,54 \\
0 ., 25\end{array}$ & $\begin{array}{l}0,85 \\
0 ., 35\end{array}$ & $\begin{array}{l}0,75 \\
0,32\end{array}$ & $\begin{array}{l}0,66 \\
0,29\end{array}$ & $\begin{array}{l}0,92 \\
0,39\end{array}$ & & $\begin{array}{c}5,81 \\
1,65\end{array}$ & $\begin{array}{l}0,26 \\
0.15\end{array}$ & $\begin{array}{l}0,005 \\
0,002\end{array}$ & $\begin{array}{l}0,64 \\
0,27\end{array}$ & $\begin{array}{l}0,004 \\
0,01\end{array}$ \\
\hline 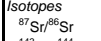 & $0.704001 \pm 9^{*}$ & $0.703938 \pm 6$ & $0.703917 \pm 10$ * & & $0.703955 \pm 8$ & & $0.703965 \pm 8$ & & & & & & & & & & & & $0.703686 \pm 6$ & & & \\
\hline${ }_{\varepsilon \mathrm{Nd}}^{14 \mathrm{Nd} /{ }^{1 / 4} \mathrm{Nd}}$ & $\begin{array}{l}0.512965 \pm 10 \\
6.38\end{array}$ & $\begin{array}{l}0.5129999 \pm 6 \\
0.712\end{array}$ & $\begin{array}{l}0.512988 \pm \pm 6 \\
6092\end{array}$ & & $\begin{array}{l}0.512984 \pm 4 \\
.7254\end{array}$ & & $\begin{array}{l}0.512982 \pm 10 \\
6.71\end{array}$ & & & & & & & & & $\begin{array}{l}0.1392984 \pm \\
0.510 \\
0.75\end{array}$ & & & $\begin{array}{l}0.1 .53608 \pm 6 \\
0.513089 \pm 8 \\
880\end{array}$ & & & \\
\hline 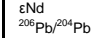 & $\begin{array}{l}6,38 \\
18.513 \pm 1\end{array}$ & $\begin{array}{l}7,04 \\
18.505 \pm 0\end{array}$ & $\begin{array}{l}6,83 \\
18.513 \pm 1\end{array}$ & & $\begin{array}{l}6,75 \\
18.519 \pm 1\end{array}$ & & $\begin{array}{l}6,71 \\
18.518 \pm 1\end{array}$ & & & & & & & & & $\begin{array}{l}6,75 \\
18.519 \pm 1\end{array}$ & & & $\begin{array}{l}8,80 \\
18.343 \pm 1\end{array}$ & & & \\
\hline 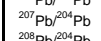 & $15.554 \pm 1$ & $\begin{array}{l}18.505 \pm 0 \\
15.545 \pm 1\end{array}$ & $\begin{array}{l}16.543 \pm 1 \\
15.53 \pm 1\end{array}$ & & $\begin{array}{l}18.519 \pm 1 \\
15.55 \pm \pm 1\end{array}$ & & $\begin{array}{l}18.518 \pm 1 \\
15.5 \pm \pm 1\end{array}$ & & & & & & & & & $\begin{array}{l}18.515 \pm 1 \\
15.550 \pm 1\end{array}$ & & & $\begin{array}{l}10.354 \pm 1 \\
15.57 \pm 1\end{array}$ & & & \\
\hline 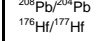 & $\begin{array}{l}38.439 \pm 3 \\
0.283161 \pm 6\end{array}$ & $\begin{array}{l}38.395 \pm 2 \\
0.283179 \pm 4\end{array}$ & $\begin{array}{l}38.381 \pm 2 \\
0.283181 \pm 9\end{array}$ & & 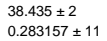 & & $\begin{array}{l}38.425 \pm 2 \\
0.283175 \pm 5\end{array}$ & & & & & & & & & $\begin{array}{l}38.423 \pm 2 \\
0.283178 \pm 5\end{array}$ & & & $\begin{array}{l}38.265 \pm 2 \\
0.283251 \pm 4\end{array}$ & & & \\
\hline$\varepsilon \mathrm{HI}$ & & & $\begin{array}{l}0.2674109 \\
14,47\end{array}$ & & $\begin{array}{l}0.26151 / \pm 11 \\
13,61\end{array}$ & & & & & & & & & & & $\begin{array}{ll}0.26,34 \\
.14\end{array}$ & & & $\begin{array}{l}0.28,951 \pm 4 \\
16,95\end{array}$ & & & \\
\hline
\end{tabular}


Click here to download Table: Table2-AFC.pdf

Table 2: Bulk D values and end member composition (most basic magmas and contaminant) input in the AFC model

\begin{tabular}{|c|c|c|c|c|c|c|c|c|c|c|c|c|c|}
\hline & & U & $\mathrm{Pb}$ & $\mathrm{Ba}$ & $Y b$ & $\mathrm{Sr}$ & $\mathrm{Hf}$ & ${ }^{206} \mathrm{~Pb} /{ }^{204} \mathrm{~Pb}$ & ${ }^{207} \mathrm{~Pb} /\left.\right|^{204} \mathrm{~Pb}$ & ${ }^{208} \mathrm{~Pb} /{ }^{204} \mathrm{~Pb}$ & ${ }^{87} \mathrm{Sr} l^{86} \mathrm{Sr}$ & ${ }^{176} \mathrm{Hf} /{ }^{177} \mathrm{Hf}$ & $r$ \\
\hline & Bulk D & 0.03 & 0.13 & 0.11 & 0.58 & 0.52 & 0.11 & & & & & & \\
\hline \multirow{2}{*}{ 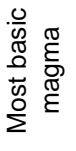 } & Pre-1960: LO15 & 0.212 & 2.29 & 97 & 1.91 & 288 & 1.39 & 18.513 & 15.554 & 38.439 & 0.704001 & 0.283161 & \\
\hline & Post-1960: LO03 & 0.260 & 2.62 & 135 & 1.78 & 359 & 1.35 & 18.512 & 15.549 & 38.425 & 0.704035 & 0.283174 & \\
\hline \multirow{2}{*}{ 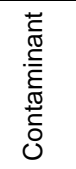 } & $\begin{array}{c}C_{a} \text { and } R_{a} \text { pre-1960: } \\
1 \% \text { partial melt }\end{array}$ & 1.189 & 2.28 & 58.2 & 5.32 & 176 & 19.0 & 18.50 & 15.48 & 38.07 & 0.7033 & 0.28319 & 0.2 \\
\hline & $\begin{array}{c}C_{a} \text { and } R_{a} \text { post-1960: } \\
10 \% \text { partial melt }\end{array}$ & 0.369 & 1.41 & 32.7 & 4.93 & 159 & 10.7 & 17.90 & 15.48 & 38.07 & 0.7033 & 0.28319 & 0.3 \\
\hline
\end{tabular}




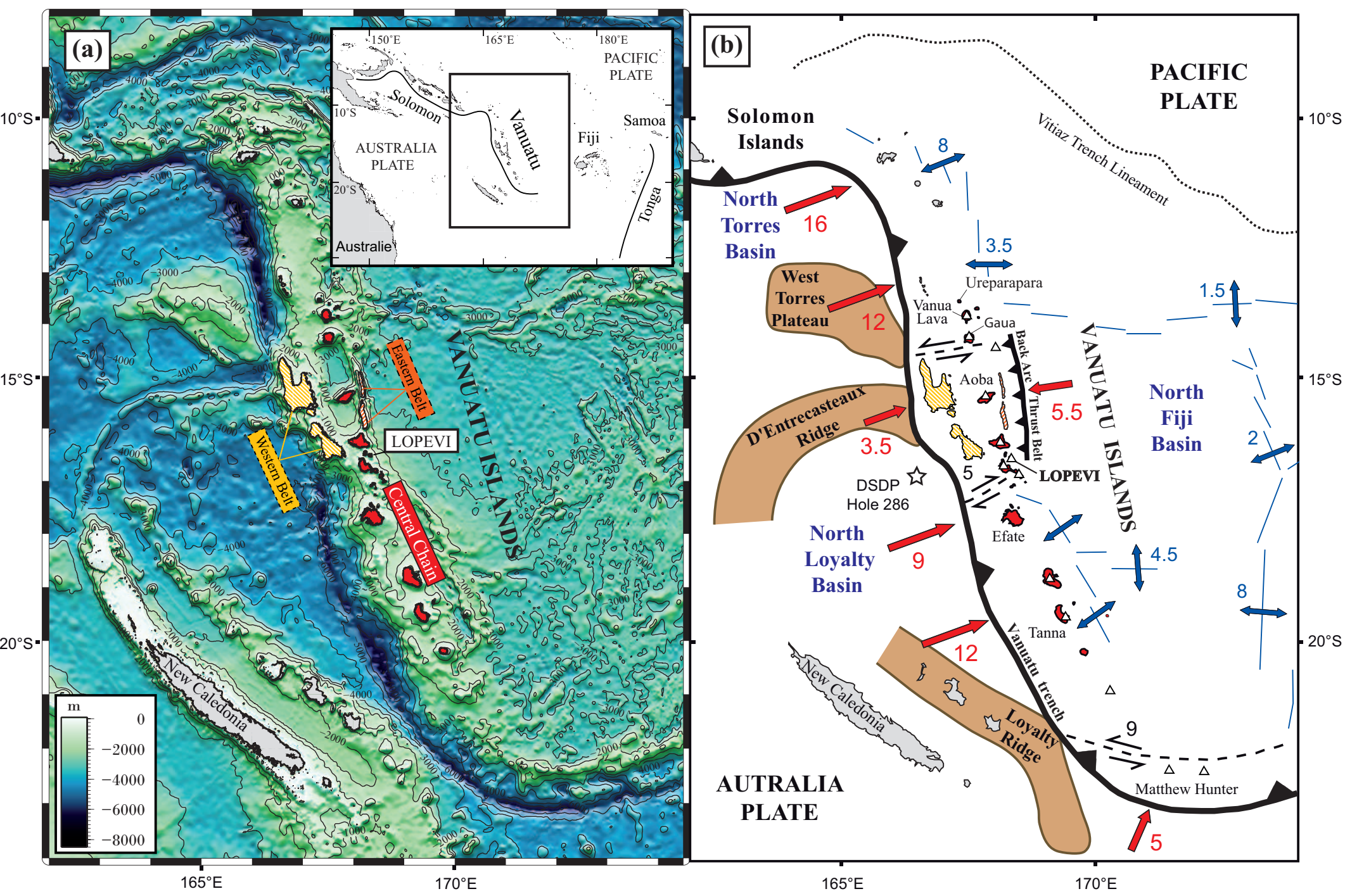




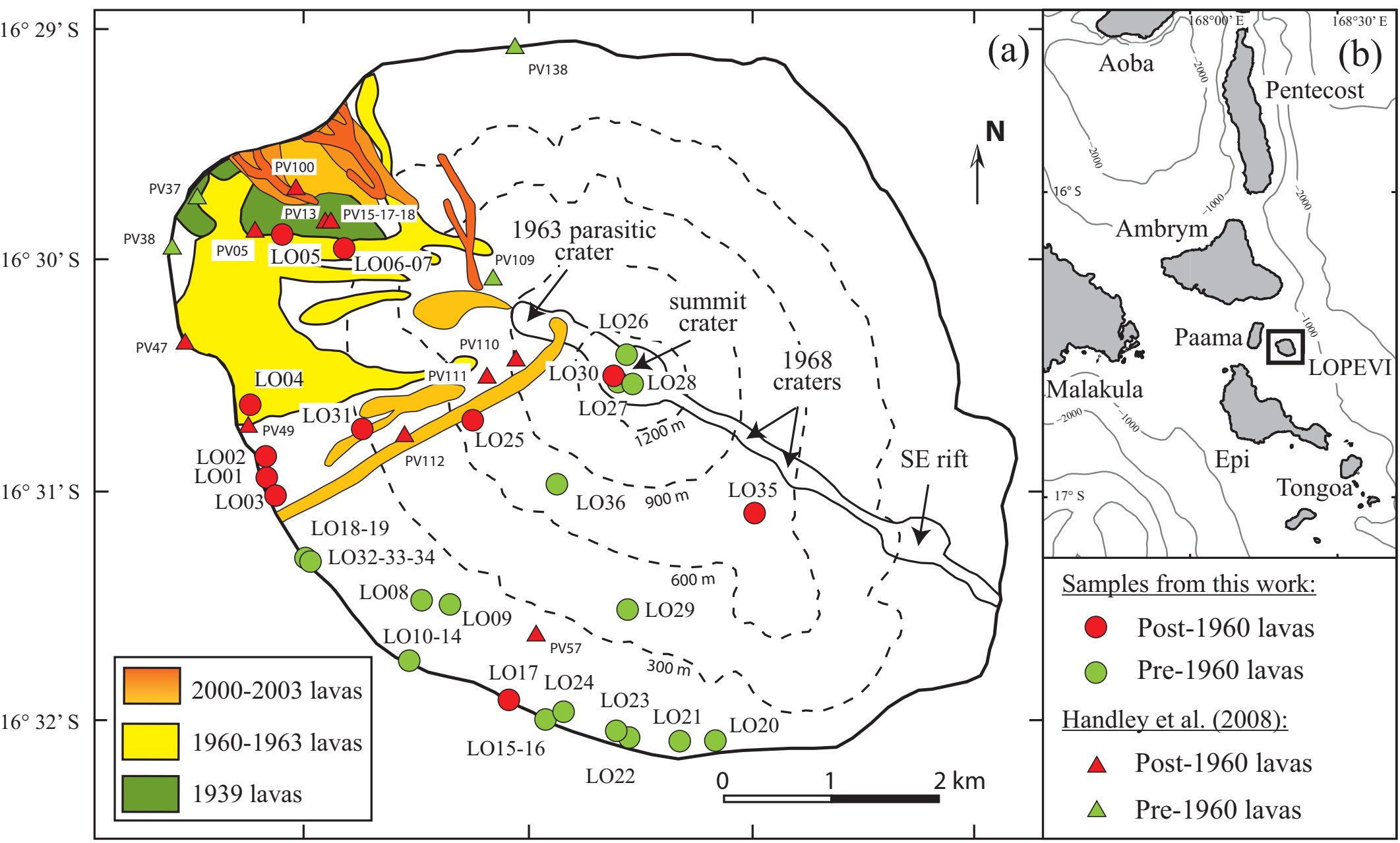

Figure 2 


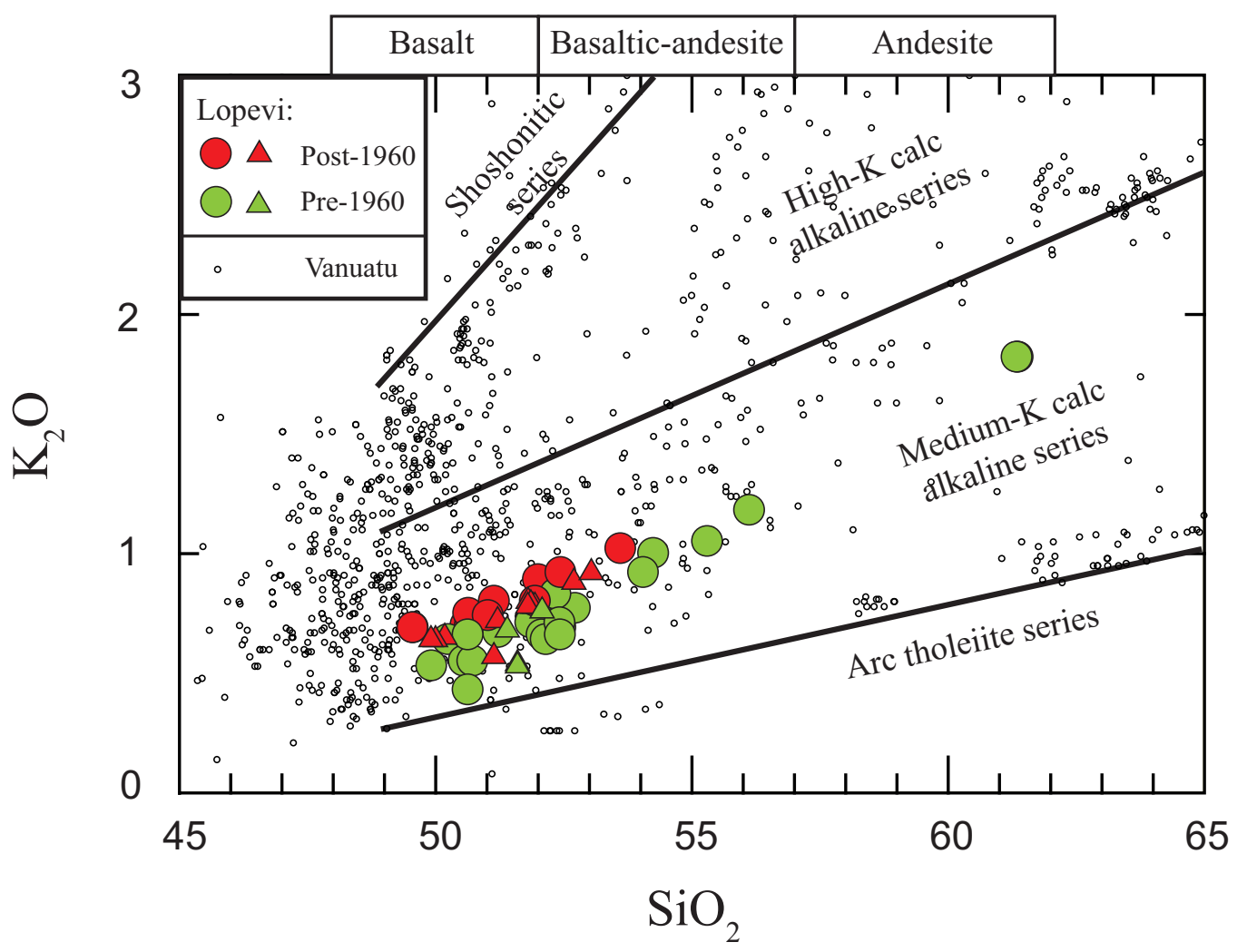

Figure 3 


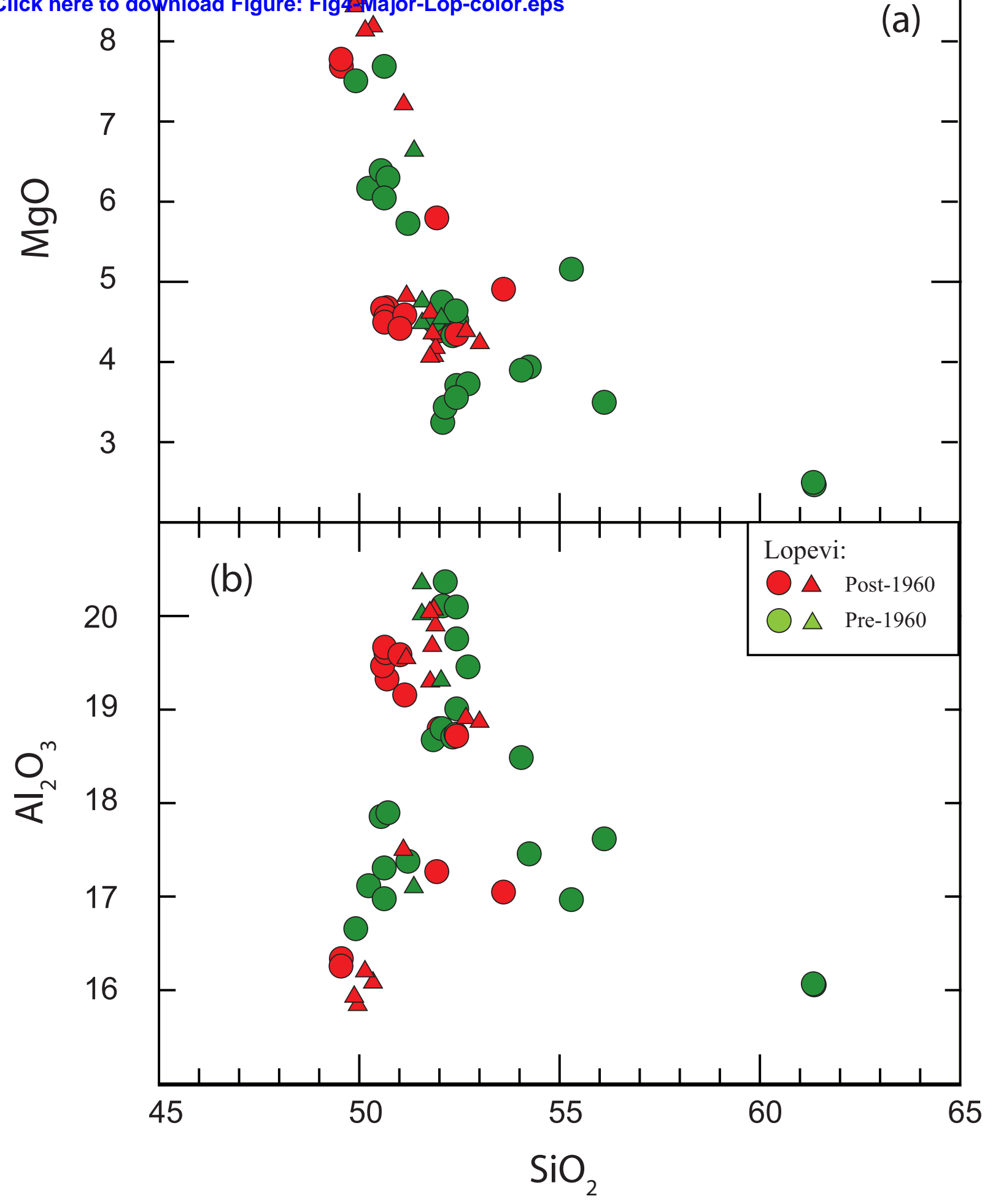

Figure 4 

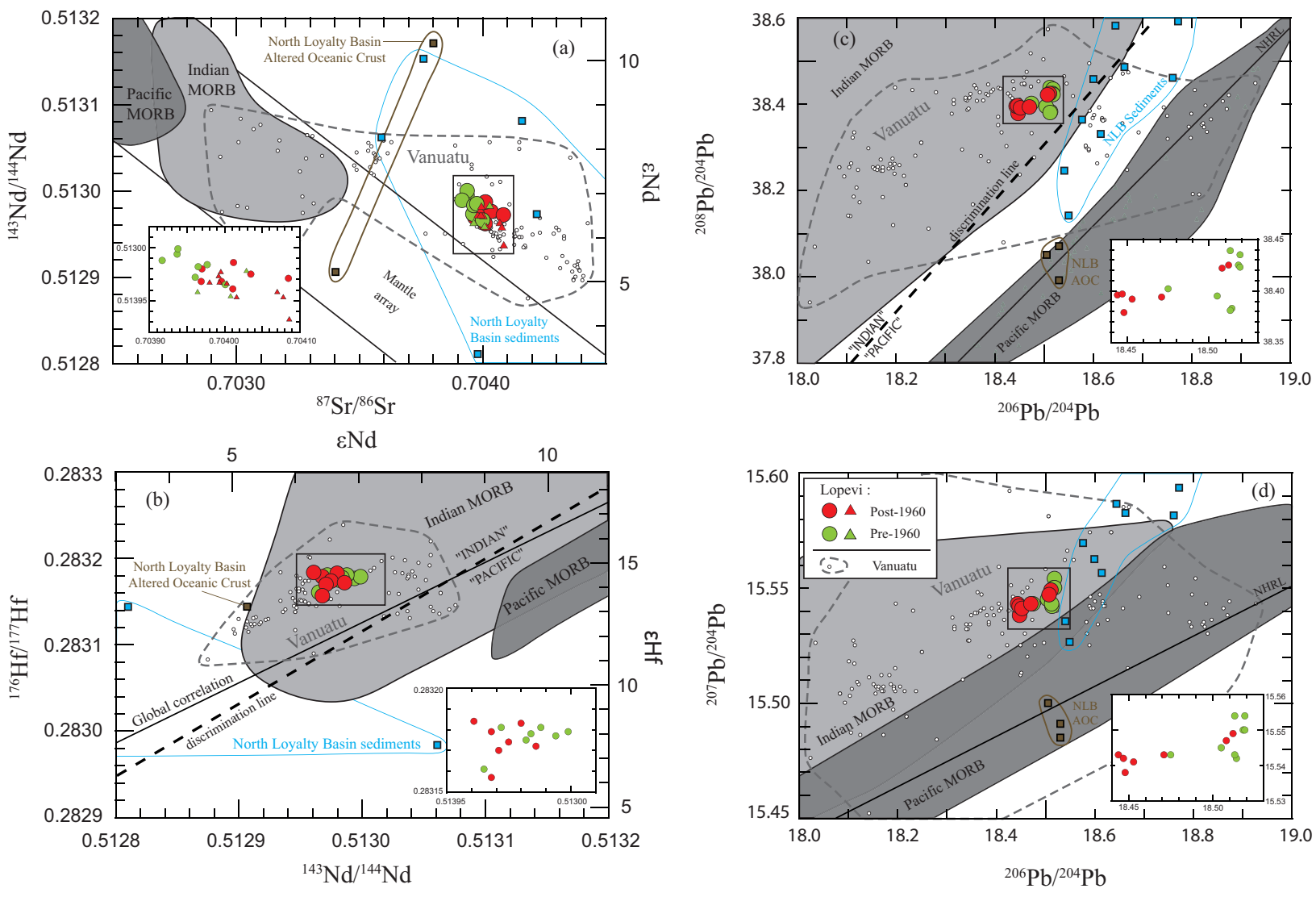

Figure 7 
Click RerkQAdduftead Figure: Fig8-AFC_Pb-Sr-NdvsSiO2-color.eps

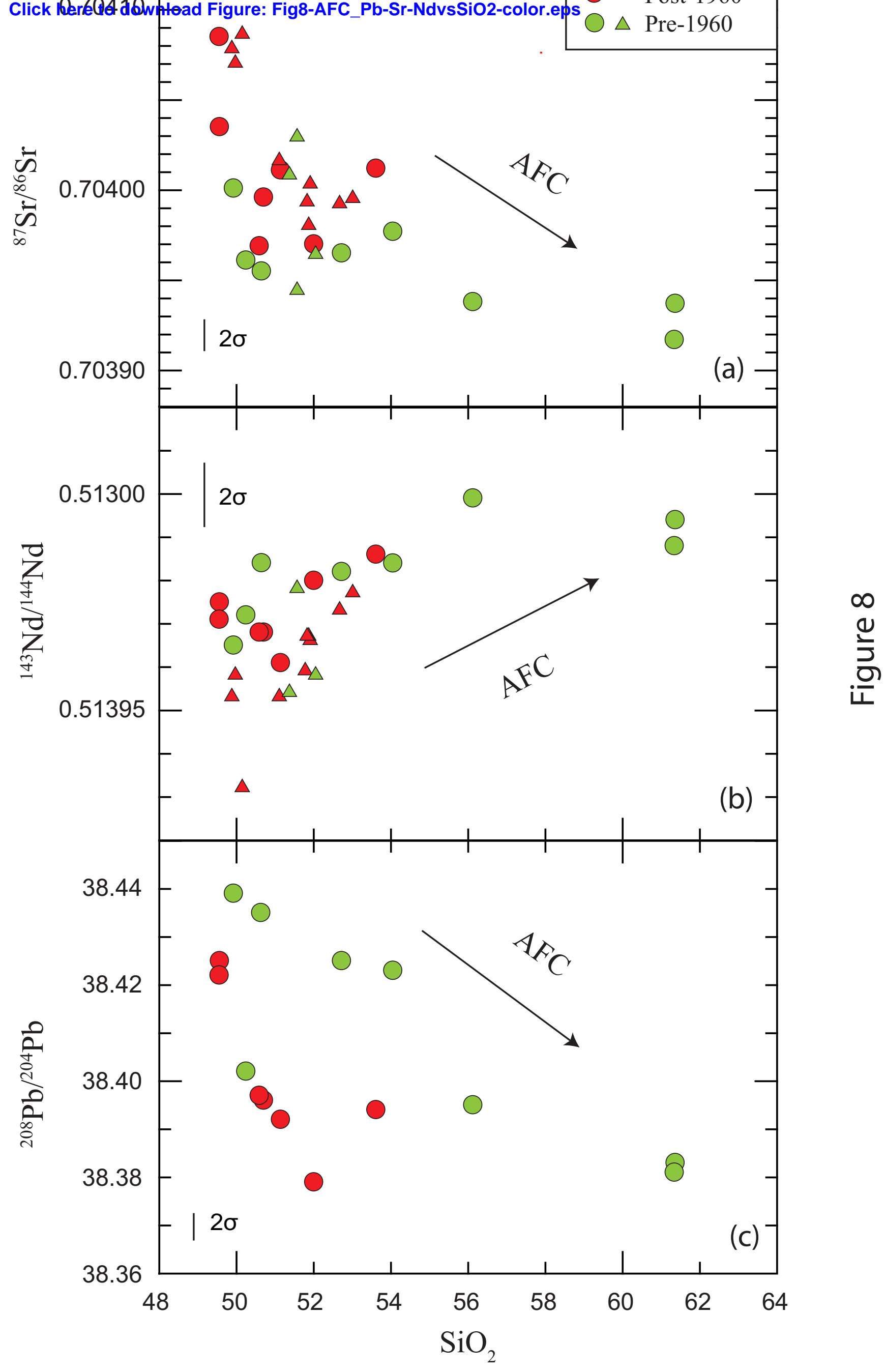




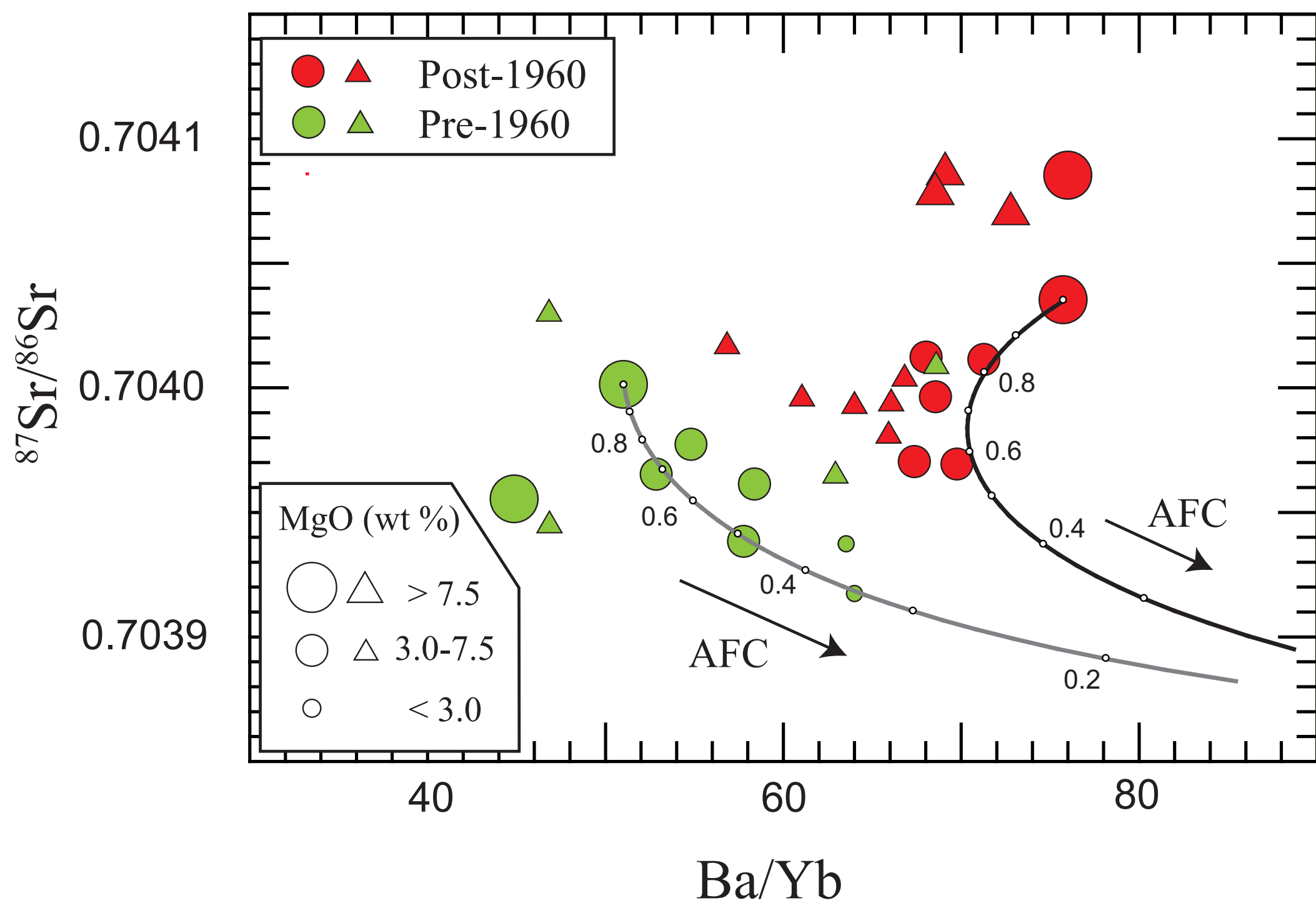

Figure 10 


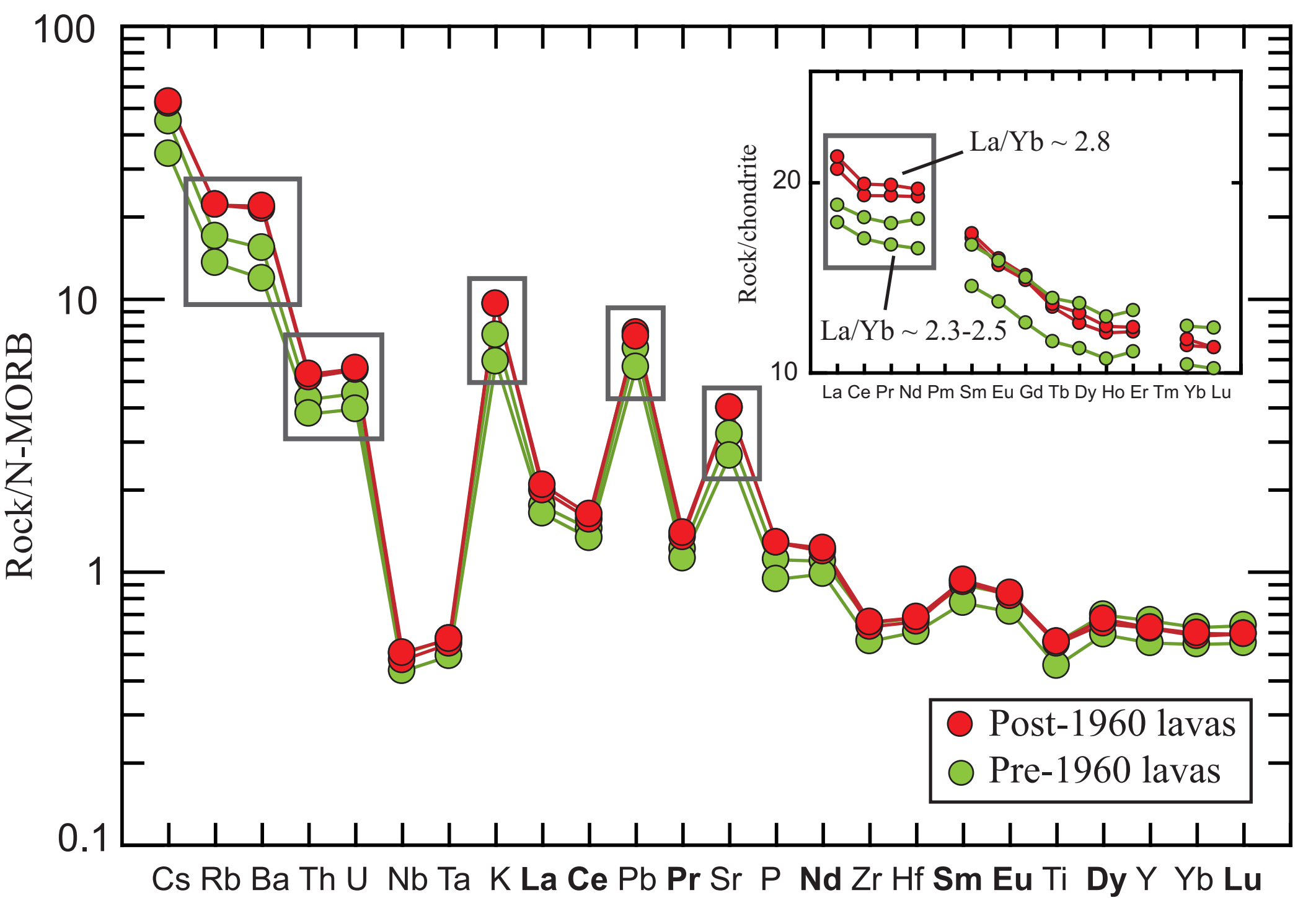

Figure 11 